\title{
Stable carbon isotope discrimination and microbiology of methane formation in tropical anoxic lake sediments
}

\author{
R. Conrad ${ }^{1}$, M. Noll ${ }^{2}$, P. Claus ${ }^{1}$, M. Klose ${ }^{1}$, W. R. Bastos ${ }^{3}$, and A. Enrich-Prast ${ }^{4}$ \\ ${ }^{1}$ Max-Planck-Institute for Terrestrial Microbiology, Karl-von-Frisch-Str. 10, 35043 Marburg, Germany \\ ${ }^{2}$ BfR, Federal Institute for Risk Assessment, Division 74 "Hygiene and Microbiology", Diedersdorferweg 1, \\ 12277 Berlin, Germany \\ ${ }^{3}$ Laboratory of Environmental Biogeochemistry, University Federal of Rondonia, Rondonia, Brazil \\ ${ }^{4}$ Laboratory of Biogeochemistry, Department of Ecology, Institute of Biology, University Federal of Rio de Janeiro, Brazil
}

Received: 30 October 2010 - Published in Biogeosciences Discuss.: 30 November 2010

Revised: 1 March 2011 - Accepted: 4 March 2011 - Published: 25 March 2011

\begin{abstract}
Methane is an important end product of degradation of organic matter in anoxic lake sediments. Methane is mainly produced by either reduction of $\mathrm{CO}_{2}$ or cleavage of acetate involving different methanogenic archaea. The contribution of the different methanogenic paths and of the diverse bacteria and archaea involved in $\mathrm{CH}_{4}$ production exhibits a large variability that is not well understood. Lakes in tropical areas, e.g. in Brazil, are wetlands with high potential impact on the global $\mathrm{CH}_{4}$ budget. However, they have hardly been studied with respect to methanogenesis. Therefore, we used samples from 16 different lake sediments in the Pantanal and Amazon region of Brazil to measure production of $\mathrm{CH}_{4}, \mathrm{CO}_{2}$, analyze the content of ${ }^{13} \mathrm{C}$ in the products and in intermediately formed acetate, determine the abundance of bacterial and archaeal microorgansisms and their community composition and diversity by targeting the genes of bacterial and archaeal ribosomal RNA and of methyl coenzyme M reductase, the key enzyme of methanogenic archaea. These experiments were done in the presence and absence of methyl fluoride, an inhibitor of acetoclastic methanogenesis. While production rates of $\mathrm{CH}_{4}$ and $\mathrm{CO}_{2}$ were correlated to the content of organic matter and the abundance of archaea in the sediment, values of ${ }^{13} \mathrm{C}$ in acetate, $\mathrm{CO}_{2}$, and $\mathrm{CH}_{4}$ were related to the ${ }^{13} \mathrm{C}$ content of organic matter and to the path of $\mathrm{CH}_{4}$ production with its intrinsic carbon isotope fractionation. Isotope fractionation was small (average 10\%o) for conversion of $\mathrm{C}_{\text {org }}$ to acetate-methyl, which was hardly further fractionated during $\mathrm{CH}_{4}$ production. However, fraction-
\end{abstract}

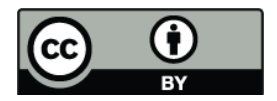

Correspondence to: R. Conrad (conrad@mpi-marburg.mpg.de) ation was strong for $\mathrm{CO}_{2}$ conversion to $\mathrm{CH}_{4}$ (average 75\%o), which generally accounted for $>50 \%$ of total $\mathrm{CH}_{4}$ production. Canonical correspondence analysis did not reveal an effect of microbial community composition, despite the fact that it exhibited a pronounced variability among the different sediments.

\section{Introduction}

Methane, an important greenhouse gas, is predominantly produced as an end product of the degradation of organic matter under anoxic conditions (Cicerone and Oremland, 1988). The actual $\mathrm{CH}_{4}$ formation is catalyzed by methanogenic archaea that mainly use acetate or $\mathrm{H}_{2}+\mathrm{CO}_{2}$ as substrates, which in turn are the products of anaerobic organic matter degradation (Zinder, 1993). The relative contribution of acetotrophic and hydrogenotrophic methanogenesis to total $\mathrm{CH}_{4}$ production significantly affects the $\delta^{13} \mathrm{C}$ of the produced $\mathrm{CH}_{4}$, since hydrogenotrophic methanogenesis expresses a larger kinetic isotope effect than acetotrophic methanogenesis (Whiticar et al., 1986). Since computation of global budget is constrained by the $\delta^{13} \mathrm{C}$ of atmospheric $\mathrm{CH}_{4}$, knowledge of the processes involved in $\mathrm{CH}_{4}$ turnover is important (Quay et al., 1991; Tyler, 1992). The processes involved in microbial $\mathrm{CH}_{4}$ production during anaerobic degradation of organic matter constitute the most important sources in the global $\mathrm{CH}_{4}$ cycle and occur in natural wetlands, in rice fields and other artificial wetlands, in the intestine of ruminants and termites, and in waste treatment systems (sewage, landfills). Natural wetlands are one of the largest individual sources accounting for $20-30 \%$ of the total

Published by Copernicus Publications on behalf of the European Geosciences Union. 
atmospheric $\mathrm{CH}_{4}$ budget (Lelieveld et al., 1998). The contribution of lake and river sediments to $\mathrm{CH}_{4}$ emission was found to offset the continental carbon sink in terms of terrestrial greenhouse gas balance (Bastviken et al., 2011). Lakes within the floodplain of South American rivers (Amazon, Pantanal, Orinoco) have been found to be a particularly significant source of atmospheric $\mathrm{CH}_{4}$ (Bastviken et al., 2010; Devol et al., 1990; Marani and Alvala, 2007; Smith et al., 2000). However, the processes involved in $\mathrm{CH}_{4}$ formation and their effects on the $\delta^{13} \mathrm{C}$ of $\mathrm{CH}_{4}$ have hardly been studied (Conrad et al., 2010b; Wassmann et al., 1992). Therefore, we decided studying lake sediments in tropical Brazil, and randomly selected sites within the Pantanal and Amazon region that were relatively easily accessible.

Methane production is achieved by a community of different microbial groups, which catalyze the stepwise degradation of organic matter (McInerney and Bryant, 1981; Zehnder, 1978). The process is initiated by the hydrolysis of polymers (e.g., polysaccharides) to monomers (e.g., sugars), which are then fermented by a variety of different bacteria to low-molecular-weight fatty acids, alcohols, $\mathrm{CO}_{2}$, and $\mathrm{H}_{2}$. Acetate is usually the most important primary fermentation product. Some bacteria can dissimilate sugars to acetate as sole product (homoacetogenesis), two acetate being produced by fermentation of the sugar and one acetate by $\mathrm{CO}_{2}$ reduction via the acetyl-CoA pathway (Dolfing, 1988; Drake and Küsel, 2003; Lever et al., 2010). However, acetate is also produced during secondary fermentation, during which primary fermentation products are further processed, or during chemolithoautotrophic homoacetogenesis $\left(4 \mathrm{H}_{2}+2 \mathrm{CO}_{2} \rightarrow \mathrm{CH}_{3} \mathrm{COO}^{-}+\mathrm{H}^{+}+2 \mathrm{H}_{2} \mathrm{O}\right)$ (Dolfing, 1988; Drake and Küsel, 2003; Lever et al., 2010). The final fermentation products are generally acetate, $\mathrm{CO}_{2}$, and $\mathrm{H}_{2}$. The last step in organic matter degradation is then the production of $\mathrm{CH}_{4}$ from the dismutation of acetate (acetoclastic methanogenesis: $\mathrm{CH}_{3} \mathrm{COOH} \rightarrow \mathrm{CH}_{4}+\mathrm{CO}_{2}$ ) and from the reduction of $\mathrm{CO}_{2}$ (hydrogenotrophic methanogenesis: $4 \mathrm{H}_{2}$ $+\mathrm{CO}_{2} \rightarrow \mathrm{CH}_{4}+2 \mathrm{H}_{2} \mathrm{O}$ ) (Schink and Stams, 2006; Zinder, 1993). Methane can potentially also be formed from methylated compounds, such as methanol, but in freshwater systems such precursors have always been found to be of minor importance (Conrad and Claus, 2005; Lovley and Klug, 1983). Each step of organic matter degradation is crucial for the entire process and for $\mathrm{CH}_{4}$ production. In systems with a dynamic input of organic matter, the degradation process may result in transient accumulation of intermediates, particularly acetate (Drake and Küsel, 2003). Thus, $\mathrm{CH}_{4}$ production rates may be limited by each of the degradation steps involved. Only if the system eventually achieves steady state are $\mathrm{CH}_{4}$ production rates limited by the first initiating reaction step, the hydrolysis of complex organic matter (Billen, 1982).

The $\delta^{13} \mathrm{C}$ of the produced $\mathrm{CH}_{4}$ depends on several factors. One, mentioned above, is the different isotope fractionation during acetoclastic versus hydrogenotrophic $\mathrm{CH}_{4}$ formation. This difference has been exploited for characterization of the predominant path of $\mathrm{CH}_{4}$ formation (Conrad, 2005). This characterization can be done in a diagnostic way by comparing the $\delta^{13} \mathrm{C}$ in both $\mathrm{CH}_{4}$ and $\mathrm{CO}_{2}$ (Hornibrook et al., 2000; Whiticar, 1999), or by quantification of the percent contribution of each path using mass balance equations based on the measurement of $\delta^{13} \mathrm{C}$ in $\mathrm{CH}_{4}, \mathrm{CO}_{2}$ and acetate and on the knowledge of fractionation factors (Alperin et al., 1992). The latter approach, requiring a rather comprehensive analysis of $\delta^{13} \mathrm{C}$ has not very often been applied (Avery et al., 1999; Conrad et al., 2009; 2010b; Sugimoto and Wada, 1993). Quantification of the hydrogenotrophic versus acetoclastic methanogenic paths by radiotracer technique also has not been used very often (reviewed by Conrad, 1999). However, these studies showed that the path of $\mathrm{CH}_{4}$ production can vary to a large extent between different environments. It is presently unclear which environmental factors, including microbiological data, control the path of $\mathrm{CH}_{4}$ production. Therefore, we decided to investigate these parameters in several different lake sediments.

The $\delta^{13} \mathrm{C}$ of the produced $\mathrm{CH}_{4}$ is not only dependent on the fractionation during $\mathrm{CH}_{4}$ production but also on the $\delta^{13} \mathrm{C}$ of the substrate from which it is produced. A classical example of this interdependence is the use of $\delta^{13} \mathrm{C}$ of $\mathrm{CO}_{2}$ and $\mathrm{CH}_{4}$ for calculation of an apparent fractionation factor $\alpha_{\mathrm{C}-\text { app }}$ that is diagnostic for whether $\mathrm{CH}_{4}$ is produced predominantly by hydrogenotrophic or acetoclastic methanogenesis. This diagnosis was pioneered by Whiticar et al. (1986) who used the synonym terms carbonate reduction and methyl fermentation, respectively. However, $\mathrm{CO}_{2}$ is not only a substrate for methanogenesis, but is first of all a product of organic matter degradation. The same is the case with acetate, which is consumed by acetoclastic methanogenesis, while is produced by fermenting or chemolithoautotrophic homoacetogenic bacteria (Heuer et al., 2010). The $\mathrm{CO}_{2}$ and acetate may also have undergone stable isotope fractionation during the course of formation. Natural organic matter, the primary substrate, in turn is the product of photosynthesis, which fractionates stable carbon isotopes during assimilation of atmospheric $\mathrm{CO}_{2}$ depending on the enzymatic mechanism (Zhang et al., 2002). Little is known how environmental conditions affect the isotopic composition of the substrates involved in methanogensis. We therefore studied ${ }^{13} \mathrm{C}$ stable isotopes in several different lake sediments.

All the conversions and isotope fractionations during methanogenic degradation of organic matter are achieved by the microbial community in the respective environment. The microbial community is composed of a large diversity of bacteria and archaea which potentially may change from site to site. Most of these microorganisms have never been isolated so that their physiological characteristics are unknown (Pace, 1997; Rappe and Giovannoni, 2003). However, it is possible to gain information about diversity and structure of the microbial community by molecular fingerprinting and sequencing techniques (Amann et al., 1995). Thus it is possible 
to analyse the diversity of bacterial and archaeal communities by targeting the gene coding for synthesis of ribosomal RNA, which is ubiquitous in all life (Woese, 2000). Furthermore, it is possible to analyze the diversity of particularly the methanogenic archaea by targeting the mcrA gene coding for a subunit of the methyl coenzyme $M$ reductase, the key enzyme involved in $\mathrm{CH}_{4}$ production (Lueders et al., 2001). However, microbial communities in tropical or subtropical lake sediments have hardly been studied in the context of biogeochmical activities, such as $\mathrm{CH}_{4}$ production and ${ }^{13} \mathrm{C}$ isotopic conversion (Conrad et al., 2010b; Nüsslein et al., 2001; 2003).

We studied 16 different lake sediments from the world largest tropical freshwater wetlands by measuring production rates of $\mathrm{CH}_{4}$ and $\mathrm{CO}_{2}$, analyzing many different variables and parameters involved in $\mathrm{CH}_{4}$ production, analyzing the $\delta^{13} \mathrm{C}$ of $\mathrm{CH}_{4}, \mathrm{CO}_{2}$, acetate (carboxyl and methyl group), and organic matter, determining isotopic fractionation factors, and analyzing the abundance and composition of microbial communities. The objective was to find out which environmental variables control (1) the path of $\mathrm{CH}_{4}$ production, (2) its rate, and (3) the $\delta^{13} \mathrm{C}_{\text {of }} \mathrm{CH}_{4}$, and its precursors.

\section{Methods}

\subsection{Sampling}

Sediment cores $(6 \mathrm{~cm}$ diameter, $40 \mathrm{~cm}$ length) of floodplain lakes from the Amazon and Pantanal regions located in Brazil were taken using a corer sampler. The upper 0$3 \mathrm{~cm}$ sediment were placed into plastic bottles and completely filled. The bottles were shipped by air freight to Marburg (Germany) and there processed immediately. The sites, sampling time and main characteristics of the sediments are shown in Table 1 and are consecutively numbered (\#1-\#16). Some of the sites are identical to those described by Bastviken et al. (2010). The sediment of Pantanal Lake 1 was sampled in 2007 during the beginning of the wet season from the center (\#8) and the margin (\#9) of the lake, and sampled again in 2008 (\#7) during the dry season from the center of the lake.

\subsection{Incubation experiments}

The incubation procedure was basically the same as described by Conrad et al. (2007, 2010b). About 9-mL aliquots of the sediment were transferred in triplicate into $27-\mathrm{mL}$ sterile tubes, flushed with $\mathrm{N}_{2}$, closed with butyl rubber stoppers and incubated over night at $25^{\circ} \mathrm{C}$. The exact amount of sediment was determined gravimetrically. Then, the bottles were flushed again with $\mathrm{N}_{2}$ and further incubated at $25^{\circ} \mathrm{C}$. The gas headspace of some of the bottles was supplemented with $2.0 \% \mathrm{CH}_{3} \mathrm{~F}$ (Fluorochrome company) to specifically inhibit acetoclastic methanogenesis (Janssen and Frenzel, 1997).
Gas samples were taken repeatedly during the course of incubation and analyzed for $\mathrm{CH}_{4}, \mathrm{CO}_{2}$, and $\delta^{13} \mathrm{C}$ of $\mathrm{CH}_{4}$ and $\mathrm{CO}_{2}$. At the end of incubation, the bottles were sacrificed for sampling of the liquid phase. Aliquots of the sediment slurry were centrifuged and the supernatants were filtered through $0.2-\mu \mathrm{m}$ polytetrafluoroethylene (PTFE) membrane filters and stored frozen $\left(-20^{\circ} \mathrm{C}\right)$ for later analysis of concentration and $\delta^{13} \mathrm{C}$ of acetate. The $\delta^{13} \mathrm{C}$ of organic carbon $\left(\delta^{13} \mathrm{C}_{\mathrm{org}}\right)$ was analyzed after air drying of the sediment at room temperature, removal of carbonate carbon by addition of $\mathrm{HCl}$, followed again by air drying of the sediment slurry at room temperature. All values are given per gram dry sediment (g$\left.\mathrm{dw}^{-1}\right)$.

\subsection{Molecular analysis of the methanogenic archaeal community}

The desoxyribonucleic acid (DNA) of the sediment samples was extracted with the Soil DNA Isolation Kit (MP) following the manufacturer's instructions as described in detail by Kolb et al. (2005). The abundance of archaeal and bacterial $16 \mathrm{~S}$ ribosomal ribonucleic acid (rRNA) gene copies was determined by real-time polymerase chain reaction (PCR) as described before (Conrad et al., 2008). Terminal restriction length polymorphism (T-RFLP) analysis of the 16S rRNA and $m c r A$ genes were done as described previously in detail (Conrad et al., 2008; Noll et al., 2010). The mcrA gene codes for a subunit of the methyl coenzyme $\mathrm{M}$ reductase, the key enzyme of $\mathrm{CH}_{4}$ production that is unique to methanogenic archaea. Correspondence analysis and canonical correspondence analysis was done as described before (Conrad et al., 2008; Noll et al., 2010). Diversity indices richness $(S)$, evenness $(E)$ and Shannon index $(H)$ of T-RFLP profiles were calculated. Richness was defined as the number of T-RFs with a relative abundance $>1 \%$ within a given T-RFLP profile. To compare the dominance structure of the respective community structures as reflected by T-RFLP analysis, the evenness of the community fingerprint patterns was calculated as $E=\left(-\Sigma \mathrm{A} p_{i} \ln \mathrm{A} p_{i}\right) / \ln S$, where A $p$ is the fluorescence intensity of the $i$-th T-RF relative to the total fluorescence intensity, and $S$ is the total number of T-RFs. The Shannon index was calculated as $H=-\Sigma \mathrm{A} p_{i} \log \mathrm{A} p_{i}$.

\subsection{Chemical analyses}

Methane, $\mathrm{CO}_{2}$, and $\mathrm{H}_{2}$ were analyzed by gas chromatography, acetate (and other fatty acids) by high pressure liquid chromatography (HPLC) as described by Conrad et al. (2007). The $\mathrm{C}$ and $\mathrm{N}$ content of the sediments were quantified on a CHNS-elemental analyzer by the Analytical Chemical Laboratory of the University of Marburg. Sulfate was analyzed by ion chromatography and total iron by the ferrozin method (Conrad and Klose, 2006). The $\delta^{13} \mathrm{C}$ (in units of permil) of $\mathrm{CH}_{4}\left(\delta^{13} \mathrm{C}_{\mathrm{CH}_{4}}\right)$ and $\mathrm{CO}_{2}\left(\delta^{13} \mathrm{C}_{\mathrm{CO}_{2}}\right)$ was analyzed by gas chromatography combustion isotope 
Table 1. Sites of the lakes and main characteristics; mean \pm SE, $n=3$.

\begin{tabular}{|c|c|c|c|c|c|c|c|c|c|c|}
\hline \# & Lake & Region & Sampling time & Coordinates & $\mathrm{pH}$ & $\mathrm{C}_{\text {org }}(\%)$ & $\delta^{13} \mathrm{C}_{\text {org }}$ & $\mathrm{N}_{\text {tot }}(\%)$ & $\begin{array}{r}\mathrm{Fe} \\
\left(\mu \mathrm{molg} \mathrm{dw}^{-1}\right)\end{array}$ & $\begin{array}{c}\text { Sulfate } \\
(\mu \mathrm{M})\end{array}$ \\
\hline 1 & Arrozal & Pantanal & July 2007 & $\mathrm{~S} 19^{\circ} 00^{\prime} 50^{\prime \prime} \mathrm{W} 57^{\circ} 31^{\prime} 27^{\prime \prime}$ & 6.3 & $6.3 \pm 0.2$ & $-25.2 \pm 0.1$ & $0.63 \pm 0.03$ & $99 \pm 1$ & 6 \\
\hline 2 & Sinibu & Pantanal & July 2007 & $\mathrm{~S} 19^{\circ} 00^{\prime} 57^{\prime \prime} \mathrm{W} 57^{\circ} 24^{\prime} 17^{\prime \prime}$ & 6.4 & $5.8 \pm 0.5$ & $-27.1 \pm 0.1$ & $0.49 \pm 0.05$ & $159 \pm 0$ & 3 \\
\hline 3 & Jatoba & Pantanal & July 2007 & $\mathrm{~S} 19^{\circ} 02^{\prime} 2^{\prime \prime} \mathrm{W} 57^{\circ} 22^{\prime} 7^{\prime \prime}$ & 6.5 & $0.8 \pm 0.3$ & $-29.3 \pm 0.1$ & $<0.05$ & $38 \pm 1$ & 3 \\
\hline 4 & Anzol de Ouro & Pantanal & July 2007 & $\mathrm{~S} 19^{\circ} 00^{\prime} 58^{\prime \prime} \mathrm{W} 57^{\circ} 37^{\prime} 29^{\prime \prime}$ & 6.9 & $12.5 \pm 0.3$ & $-28.0 \pm 0.1$ & $1.06 \pm 0.04$ & $286 \pm 1$ & 15 \\
\hline 5 & Teresa & Pantanal & November 2008 & $\mathrm{~S} 18^{\circ} 57^{\prime} 38^{\prime \prime} \mathrm{W} 57^{\circ} 26^{\prime} 28^{\prime \prime}$ & 6.8 & $1.7 \pm 0.5$ & $-27.9 \pm 0.3$ & $0.11 \pm 0.02$ & $105 \pm 0$ & 0 \\
\hline 6 & Presa & Pantanal & November 2008 & $\mathrm{~S} 18^{\circ} 59^{\prime} 0^{\prime \prime} \mathrm{W} 57^{\circ} 25^{\prime} 0^{\prime \prime}$ & 6.7 & $0.8 \pm 0.1$ & $-27.6 \pm 0.5$ & $0.07 \pm 0.01$ & $74 \pm 1$ & 1 \\
\hline 7 & Lobo & Pantanal & November 2008 & $\mathrm{~S} 18^{\circ} 57^{\prime} 7^{\prime \prime} \mathrm{W} 57^{\circ} 36^{\prime} 54^{\prime \prime}$ & 6.6 & $5.9 \pm 0.1$ & $-26.9 \pm 0.1$ & $0.55 \pm 0.02$ & $46 \pm 0$ & 1 \\
\hline 8 & Lake 1, central & Pantanal & November 2008 & $\mathrm{~S} 19^{\circ} 1^{\prime} 45^{\prime \prime} \mathrm{W} 57^{\circ} 32^{\prime} 54^{\prime \prime}$ & 7.7 & $8.5 \pm 0.2$ & $-29.2 \pm 1.9$ & $0.69 \pm 0.01$ & $49 \pm 1$ & 0 \\
\hline 9 & Lake 1 , margin & Pantanal & January 2007 & $\mathrm{~S} 19^{\circ} 1^{\prime} 45^{\prime \prime} \mathrm{W} 57^{\circ} 32^{\prime} 54^{\prime \prime}$ & 6.5 & $11.7 \pm 1.4$ & $-30.1 \pm 0.1$ & $0.97 \pm 0.08$ & $150 \pm 2$ & 60 \\
\hline 10 & Lake 1 , central & Pantanal & January 2007 & $\mathrm{~S} 19^{\circ} 1^{\prime} 45^{\prime \prime} \mathrm{W} 57^{\circ} 32^{\prime} 54^{\prime \prime}$ & 7.0 & $11.4 \pm 0.2$ & $-31.3 \pm 0.2$ & $0.92 \pm 0.01$ & $208 \pm 1$ & 96 \\
\hline 11 & Lake 2 & Pantanal & January 2007 & $\mathrm{~S} 19^{\circ} 1^{\prime} 50^{\prime \prime} \mathrm{W} 57^{\circ} 28^{\prime} 24^{\prime \prime}$ & 6.9 & $3.1 \pm 0.01$ & $-29.5 \pm 1.0$ & $0.26 \pm 0.01$ & $136 \pm 1$ & 36 \\
\hline 12 & Belmont & Amazonia & August 2007 & $\mathrm{~S} 08^{\circ} 39^{\prime} 3^{\prime \prime} \mathrm{W} 63^{\circ} 50^{\prime} 23^{\prime \prime}$ & 5.9 & $5.7 \pm 0.4$ & $-28.6 \pm 0.0$ & $0.44 \pm 0.00$ & $106 \pm 1$ & 4 \\
\hline 13 & Maravilha & Amazonia & August 2007 & $\mathrm{~S} 08^{\circ} 43^{\prime} 40^{\prime \prime} \mathrm{W} 63^{\circ} 55^{\prime} 52^{\prime \prime}$ & 6.5 & $2.6 \pm 0.0$ & $-29.1 \pm 0.0$ & $0.18 \pm 0.01$ & $78 \pm 0$ & 4 \\
\hline 14 & Laguinho & Amazonia & August 2007 & $\mathrm{~S} 08^{\circ} 26^{\prime} 47^{\prime \prime} \mathrm{W} 63^{\circ} 28^{\prime} 28^{\prime \prime}$ & 6.8 & $1.6 \pm 0.2$ & $-29.5 \pm 0.2$ & $0.14 \pm 0.00$ & $234 \pm 1$ & 5 \\
\hline 15 & Paca & Amazonia & August 2007 & $\mathrm{~S} 08^{\circ} 29^{\prime} 46^{\prime \prime} \mathrm{W} 63^{\circ} 27^{\prime} 56^{\prime \prime}$ & 6.7 & $4.1 \pm 0.0$ & $-32.4 \pm 0.1$ & $0.35 \pm 0.00$ & $126 \pm 1$ & 9 \\
\hline 16 & Puruzinho & Amazonia & November 2008 & $\mathrm{~S} 07^{\circ} 22^{\prime} 19^{\prime \prime} \mathrm{W} 63^{\circ} 23^{\prime} 22^{\prime \prime}$ & 7.6 & $1.9 \pm 0.0$ & $-32.8 \pm 2.5$ & $0.24 \pm 0.01$ & $279 \pm 3$ & 2 \\
\hline
\end{tabular}

ratio mass spectrometry (GC-C-IRMS), the $\delta^{13} \mathrm{C}$ of acetate $\left(\delta^{13} \mathrm{C}_{\mathrm{ac}}\right)$ by HPLC-C-IRMS as described before (Conrad et al., 2007). The $\delta^{13} \mathrm{C}$ of the methyl group of acetate $\left(\delta^{13} \mathrm{C}_{\mathrm{ac}-\text { methyl }}\right)$ was determined after off-line pyrolysis (Conrad et al., 2007). The $\delta^{13} \mathrm{C}$ of the carboxyl group of acetate $\left(\delta^{13} \mathrm{C}_{\mathrm{ac}-\text { caboxyl }}\right)$ was calculated by $\delta^{13} \mathrm{C}_{\mathrm{ac}-\text { caboxyl }}=2 \delta^{13} \mathrm{C}_{\mathrm{ac}}$ $-\delta^{13} C_{a c}$-methyl. Analysis of the $\delta^{13} \mathrm{C}$ in organic matter was done at the Institute of Soil Science and Forest Nutrition (IBW) at the University of Göttingen (courtesy of Heinz Flessa) with an elemental analyzer (Fisons EA 1108) coupled to an IRMS. The precision of repeated analysis was generally better than $\pm 0.3 \%$.

\subsection{Calculations}

Fractionation factors for a reaction $\mathrm{A} \rightarrow \mathrm{B}$ are defined after Hayes (1993):

$\delta_{\mathrm{A}, \mathrm{B}}=\left(\delta^{13} \mathrm{C}_{\mathrm{A}}+1000\right) /\left(\delta^{13} \mathrm{C}_{\mathrm{B}}+1000\right)$

sometimes expressed as isotopic enrichment factor $\varepsilon \equiv 1-$ $\alpha$ (in units of permil). The $\delta^{13} \mathrm{C}$ for a newly formed $\mathrm{CH}_{4}$ $\left(\delta^{13} \mathrm{C}_{\text {new }}\right)$ was calculated from the $\delta^{13} \mathrm{C}$ at two time points $t=1\left(\delta^{13} \mathrm{C}_{1}\right)$ and $\mathrm{t}=2\left(\delta^{13} \mathrm{C}_{2}\right)$ by the following mass balance equation:

$\delta^{13} \mathrm{C}_{2}=f_{\text {new }} \delta^{13} \mathrm{C}_{\text {new }}+\left(1-f_{\text {new }}\right) \delta^{13} C_{1}$

with $f_{\text {new }}$ being the fraction of the newly formed Ccompound relative to the total at $t=2$.

The fractionation factor for conversion of $\mathrm{CO}_{2}$ to $\mathrm{CH}_{4}$ is given by

$\alpha_{\mathrm{CO}_{2}, \mathrm{CH}_{4}}=\left(\delta^{13} \mathrm{C}_{\mathrm{CO}_{2}}+1000\right) /\left(\delta^{13} \mathrm{C}_{\mathrm{CH}_{4}-\mathrm{mc}}+1000\right)$

where $\delta^{13} \mathrm{C}_{\mathrm{CH}_{4}-\mathrm{mc}}$ is the newly formed $\mathrm{CH}_{4} \mathrm{Eq}$. (2) derived from $\mathrm{H}_{2}+\mathrm{CO}_{2}$, i.e., the $\mathrm{CH}_{4}$ produced in the presence of $2 \%$
$\mathrm{CH}_{3} \mathrm{~F}$, assuming that acetoclastic methanogenesis was then completely inhibited.

Relative contribution of $\mathrm{H}_{2}+\mathrm{CO}_{2}$-derived $\mathrm{CH}_{4}$ to total $\mathrm{CH}_{4}$ was determined using the following mass balance equation (Conrad, 2005):

$$
\begin{aligned}
& f_{\mathrm{CO}_{2}, \mathrm{CH}_{4}}=\left(\delta^{13} \mathrm{C}_{\mathrm{CH}_{4}}-\delta^{13} \mathrm{C}_{\mathrm{CH}_{4}-\mathrm{ma}}\right) / \\
& \left(\delta^{13} \mathrm{C}_{\mathrm{CH}_{4}-\mathrm{mc}}-\delta^{13} \mathrm{C}_{\mathrm{CH}_{4}-\mathrm{ma}}\right)
\end{aligned}
$$

where $f_{\mathrm{CO}_{2}, \mathrm{CH}_{4}}$ is the fraction of $\mathrm{CH}_{4}$ formed from $\mathrm{H}_{2}$ $+\mathrm{CO}_{2}, \delta^{13} \mathrm{C}_{\mathrm{CH}_{4}}$ the $\delta^{13} \mathrm{C}$ of total produced methane, $\delta^{13} \mathrm{C}_{\mathrm{CH}_{4}-\mathrm{mc}}$ the $\delta^{13} \mathrm{C}$ of $\mathrm{CH}_{4}$ derived from $\mathrm{H}_{2}+\mathrm{CO}_{2}$, and $\delta^{13} \mathrm{C}_{\mathrm{CH}_{4}-\mathrm{ma}}$ the $\delta^{13} \mathrm{C}$ of $\mathrm{CH}_{4}$ derived from acetate determined by:

$\delta^{13} \mathrm{C}_{\mathrm{CH}_{4}-\mathrm{ma}}=\delta^{13} \mathrm{C}_{\mathrm{ac}-\text { methyl }}+\varepsilon_{\mathrm{ac}, \mathrm{CH}_{4}}$

where $\delta^{13} \mathrm{C}_{\mathrm{ac}-\text {-methyl }}$ is the $\delta^{13} \mathrm{C}$ of the methyl group of acetate accumulated and $\varepsilon_{\mathrm{ac}, \mathrm{CH}_{4}}$ is the isotopic enrichment fac-

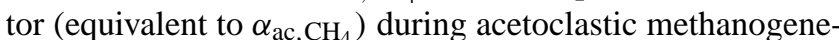
sis. It is assumed, that the methyl group of acetate was either

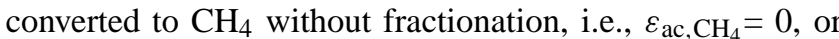
that acetate fractionation was due to Methanosaeta species with $\varepsilon_{\mathrm{ac}, \mathrm{CH}_{4}}=-10 \%$ (Penning et al., 2006; Valentine et al., 2004).

The concentrations of dissolved $\mathrm{CO}_{2}$ and bicarbonate were calculated using Henry's law and the dissociation constant of bicarbonate at $25^{\circ} \mathrm{C}$, i.e., $\mathrm{pK}=6.352$ (Stumm and Morgan, 1981). Regression analysis was done using Origin 6.1 (Microcal, Northampton, MA, USA).

\section{Results}

Sediments were sampled from 16 different lake sites in Brazilian Pantanal and Amazonia in 2006, 2007 and 2008. The geographical coordinates of the sites and some of the 
Table 2. Production rates ( $\mathrm{nmol} \mathrm{h}^{-1} \mathrm{~g}$-dw ${ }^{-1}$ ) of $\mathrm{CH}_{4}$ and $\mathrm{CO}_{2}$, values of $\delta^{13} \mathrm{C}\left(\%\right.$ ), and enrichment factor for $\mathrm{CH}_{4}$ production from $\mathrm{CO}_{2}$ in the incubations of different lake sediments with and without inhibitor $\left(2 \% \mathrm{CH}_{3} \mathrm{~F}\right)$; mean $\pm \mathrm{SE}, n=3$. Details of lake sites are explained in Table 1.

\begin{tabular}{|c|c|c|c|c|c|c|c|c|c|}
\hline \multirow{2}{*}{$\begin{array}{l}\text { Lake sites } \\
\#\end{array}$} & \multicolumn{2}{|c|}{$\mathrm{CH}_{4}$ production } & \multicolumn{2}{|c|}{$\mathrm{CO}_{2}$ production } & \multicolumn{2}{|c|}{$\delta^{13} \mathrm{C}-\mathrm{CH}_{4}$} & \multicolumn{2}{|c|}{$\delta^{13} \mathrm{C}-\mathrm{CO}_{2}$} & \multirow{2}{*}{$\underset{\text { mean }}{\alpha_{\mathrm{CO}_{2}, \mathrm{CH}_{4}}}$} \\
\hline & control & $+\mathrm{CH}_{3} \mathrm{~F}$ & control & $+\mathrm{CH}_{3} \mathrm{~F}$ & Control & $+\mathrm{CH}_{3} \mathrm{~F}$ & Control & $+\mathrm{CH}_{3} \mathrm{~F}$ & \\
\hline 1 & $3.7 \pm 0.2$ & $2.8 \pm 0.1$ & $3.7 \pm 0.2$ & $2.8 \pm 0.4$ & $-59.0 \pm 0.5$ & $-72.2 \pm 0.8$ & $-7.2 \pm 0.3$ & $-10.6 \pm 0.2$ & $1.066 \pm 0.003$ \\
\hline 3 & $2.3 \pm 0.3$ & $1.1 \pm 0.1$ & $2.0 \pm 0.2$ & $1.7 \pm 0.3$ & $-65.3 \pm 0.6$ & $-82.2 \pm 1.8$ & $-11.0 \pm 0.3$ & $-16.2 \pm 0.1$ & $1.072 \pm 0.003$ \\
\hline 4 & $14.3 \pm 0.8$ & $7.3 \pm 0.2$ & $10.2 \pm 0.1$ & $7.9 \pm 0.7$ & $-62.3 \pm 0.9$ & $-80.0 \pm 0.9$ & $-9.8 \pm 0.1$ & $-11.6 \pm 0.2$ & $1.074 \pm 0.003$ \\
\hline 5 & $0.6 \pm 0.1$ & $0.3 \pm 0.0$ & $0.6 \pm 0.1$ & $0.7 \pm 0.1$ & $-83.7 \pm 1.7$ & $-97.6 \pm 2.9$ & $-16.3 \pm 0.3$ & $-22.9 \pm 0.3$ & $1.083 \pm 0.008$ \\
\hline 6 & $1.5 \pm 0.1$ & $0.3 \pm 0.0$ & $1.0 \pm 0.0$ & $0.7 \pm 0.0$ & $-73.7 \pm 1.1$ & $-97.4 \pm 0.8$ & $-16.7 \pm 0.6$ & $-21.0 \pm 0.1$ & $1.085 \pm 0.002$ \\
\hline 8 & $2.9 \pm 0.3$ & $2.0 \pm 0.3$ & $3.6 \pm 0.2$ & $3.5 \pm 0.5$ & $-76.4 \pm 1.2$ & $-91.1 \pm 1.4$ & $-11.6 \pm 0.1$ & $-16.6 \pm 0.3$ & $1.082 \pm 0.004$ \\
\hline 9 & $9.8 \pm 0.7$ & $3.7 \pm 0.3$ & $11.6 \pm 0.6$ & $8.0 \pm 0.4$ & $-66.2 \pm 0.5$ & $-92.3 \pm 1.6$ & $-22.6 \pm 1.0$ & $-25.0 \pm 0.9$ & $1.074 \pm 0.010$ \\
\hline 10 & $8.0 \pm 1.2$ & $5.3 \pm 0.5$ & $5.4 \pm 1.0$ & $6.8 \pm 3.0$ & $-80.9 \pm 1.2$ & $-100.9 \pm 1.6$ & $-29.7 \pm 1.1$ & $-32.2 \pm 1.3$ & $1.076 \pm 0.014$ \\
\hline 11 & $2.9 \pm 0.2$ & $2.1 \pm 0.2$ & $1.8 \pm 0.3$ & $1.7 \pm 0.3$ & $-82.8 \pm 0.7$ & $-97.8 \pm 2.3$ & $-26.8 \pm 1.4$ & $-28.2 \pm 1.3$ & $1.077 \pm 0.015$ \\
\hline 12 & $4.5 \pm 0.4$ & $1.9 \pm 0.1$ & $7.0 \pm 0.1$ & $3.9 \pm 0.1$ & $-57.7 \pm 0.3$ & $-69.9 \pm 0.9$ & $-14.0 \pm 0.6$ & $-17.3 \pm 0.4$ & $1.057 \pm 0.006$ \\
\hline 13 & $1.1 \pm 0.0$ & $0.7 \pm 0.0$ & $1.5 \pm 0.1$ & $0.9 \pm 0.1$ & $-78.0 \pm 1.3$ & $-94.4 \pm 1.4$ & $-21.1 \pm 0.7$ & $-22.6 \pm 0.6$ & $1.079 \pm 0.007$ \\
\hline
\end{tabular}

basic characteristics of the sediments are given in Table 1 . The Amazonian lakes were located close to the city of Porto Velho and the Pantanal lakes were located close to the city of Ladario. In most of the sampled environments in the Pantanal there is a daily change in temperature values that can vary up to $5^{\circ} \mathrm{C}$, and oxygen concentrations can vary from $120 \%$ saturation (day) to anoxic (midnight) right over the sediment within $12 \mathrm{~h}$ (data not shown). The Amazonian lakes were mostly sampled during high water level, with a temperature average of $28^{\circ} \mathrm{C}$ during sampling and with anoxia over the sediment. The $\mathrm{pH}$ values of the lake sediments were in a range of $\mathrm{pH} 5.9$ to 7.7 (average $\mathrm{pH} 6.75$ ); the contents of organic carbon ranged between 0.8 and $12.5 \%$ (average $5.3 \%) ; \delta^{13} \mathrm{C}_{\text {org }}$ between -32.8 and $-25.2 \%$; $\mathrm{N}_{\text {tot }}$ between $<0.05 \%$ and $1.06 \%$; total iron between 46 and $286 \mu \mathrm{mol} g$ $\mathrm{dw}^{-1}$; and porewater sulfate concentrations between 0 and $96 \mu \mathrm{M}$. Hence, the chemical conditions of the lake sediments covered a rather broad range. The highest sulfate concentrations were found in samples taken in 2007 from Lake 1 and Lake 2.

The sediment samples were incubated in triplicate under anoxic conditions at $25^{\circ} \mathrm{C}$ in the absence and presence of $2 \%$ $\mathrm{CH}_{3} \mathrm{~F}$. These standard conditions guaranteed that data obtained from the different incubations were comparable and represented their methanogenic potentials. Methyl fluoride served as inhibitor of acetoclastic methanogenesis (Janssen and Frenzel, 1997). A typical experiment is shown in Fig. 1 for Lake Jatoba sediment. The experimental results of all the lake sediments are shown in supplementary Fig. S1. In Lake Jatoba as in all the other lake sediments both $\mathrm{CH}_{4}$ and $\mathrm{CO}_{2}$ were produced during the course of the experiment. Production of $\mathrm{CO}_{2}$ generally and production of $\mathrm{CH}_{4}$ in most of the lake sediments started right from the beginning of the incubation, with rates gradually decreasing with time (Fig. 1a, b). Only the sediments sampled in Lake 1 and Lake 2 in 2007, which contained relatively much sulfate (Table 1), exhibited a lag phase before $\mathrm{CH}_{4}$ production started (Fig. S1). This lag was probably due to inhibition of the methanogenic microbial community by the sulfate-reducing microbial community competing for the same substrates (Ward and Winfrey, 1985). Addition of $\mathrm{CH}_{3} \mathrm{~F}$ resulted in a lower $\mathrm{CH}_{4}$ production due to inhibition of acetoclastic methanogenesis, but usually had a much smaller effect on production of $\mathrm{CO}_{2}$. The rates are summarized in Table 2.

The $\delta{ }^{13} \mathrm{C}$ values of the accumulating $\mathrm{CH}_{4}$ and $\mathrm{CO}_{2}$ were also measured during the course of incubation (Fig. 1c). The time period for which values of $\delta^{13} \mathrm{C}_{\mathrm{CH}_{4}}$ and $\delta^{13} \mathrm{C}_{\mathrm{CO}_{2}}$ were averaged is indicated by arrows (Fig. 1c). The average values are summarized in Table 2. Values of $\delta^{13} \mathrm{C}_{\mathrm{CH}_{4}}$ of newly formed $\mathrm{CH}_{4}$ were calculated from those of accumulated $\mathrm{CH}_{4}$ using mass balance Eq. (2). The $\delta^{13} \mathrm{C}_{\mathrm{CH}_{4}}$ values across all the different lake sediments $(-71.8 \%$ o were generally much lower than values of $\delta^{13} \mathrm{C}_{\mathrm{CO}_{2}}(-17.0 \%$ ). The values of $\delta^{13} \mathrm{C}_{\mathrm{CH}_{4}}$ decreased even further $(-88.8 \%$ ) when $\mathrm{CH}_{3} \mathrm{~F}$ was added to inhibit acetoclastic methanogenesis. However, $\mathrm{CH}_{3} \mathrm{~F}$ had only a relatively small effect on values $\left(-20.8 \%\right.$ ) of $\delta^{13} \mathrm{C}_{\mathrm{CO}_{2}}$ (Table 2). Assuming that the $\mathrm{CH}_{4}$ in the presence of $\mathrm{CH}_{3} \mathrm{~F}$ was exclusively formed from reduc-

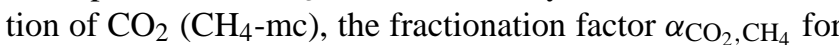
hydrogenotrophic methanogenesis was calculated from the 
Table 3. Concentrations of acetate, propionate, and values of $\delta^{13} \mathrm{C}(\%)$ in total acetate and in acetate-methyl at the end of incubation of different lake sediments with and without inhibitor $\left(2 \% \mathrm{CH}_{3} \mathrm{~F}\right)$; mean $\pm \mathrm{SE}, n=3$. Details of lake sites are explained in Table 1 .

\begin{tabular}{lccccccc}
\hline Lake sites & \multicolumn{2}{c}{ Acetate $(\mu \mathrm{M})$} & Propionate $(\mu \mathrm{M})$ & \multicolumn{2}{c}{$\delta^{13} \mathrm{C}$-acetate $(\% o)$} & \multicolumn{2}{c}{$\delta^{13} \mathrm{C}$-ac-methyl $(\%)$} \\
\hline$\#$ & control & $+\mathrm{CH}_{3} \mathrm{~F}$ & $+\mathrm{CH}_{3} \mathrm{~F}$ & control & $+\mathrm{CH}_{3} \mathrm{~F}$ & Control $^{\mathrm{b}}$ & $+\mathrm{CH}_{3} \mathrm{~F}$ \\
1 & $24 \pm 2$ & $447 \pm 13$ & $13 \pm 8$ & $-22.8 \pm 0.5$ & $-14.5 \pm 0.2$ & -31.3 & $-29.7 \pm 2.9$ \\
2 & $31 \pm 7$ & $925 \pm 156$ & $28 \pm 10$ & $-19.8 \pm 0.7$ & $-16.0 \pm 0.3$ & -26.4 & $-29.5 \pm 1.0$ \\
3 & $63 \pm 21$ & $1330 \pm 193$ & $56 \pm 13$ & $-22.1 \pm 1.6$ & $-25.0 \pm 0.5$ & -30.6 & $-37.7 \pm 0.5$ \\
4 & $21 \pm 2$ & $1217 \pm 27$ & $31 \pm 2$ & $-24.1 \pm 1.2$ & $-21.6 \pm 0.3$ & -29.8 & $-31.8 \pm 0.1$ \\
5 & $0^{\mathrm{a}}$ & $979 \pm 107$ & $46 \pm 1$ & $-37.0^{\mathrm{b}}$ & $-34.6 \pm 0.4$ & -41.1 & $-46.6 \pm 0.6$ \\
6 & $0^{\mathrm{a}}$ & $2357 \pm 104$ & $121 \pm 2$ & $-34.2^{\mathrm{b}}$ & $-34.3 \pm 0.2$ & no data $^{\mathrm{c}}$ & $-48.1 \pm 0.6$ \\
7 & $0^{\mathrm{a}}$ & $761 \pm 67$ & $0^{\mathrm{a}}$ & $-31.9^{\mathrm{b}}$ & $-22.6 \pm 0.1$ & -44.6 & $-39.8 \pm 3.2$ \\
8 & $0^{\mathrm{a}}$ & $205 \pm 12$ & $0^{\mathrm{a}}$ & $-36.5^{\mathrm{b}}$ & $-28.5 \pm 0.7$ & -45.4 & $-42.8 \pm 0.7$ \\
9 & $70 \pm 8$ & $2922 \pm 216$ & $180 \pm 16$ & $-19.8 \pm 0.4$ & $-20.8 \pm 1.4$ & -33.1 & $-31.6 \pm 1.8$ \\
10 & $62 \pm 2$ & $319 \pm 146$ & $21 \pm 2$ & $-18.7 \pm 0.3$ & $-24.5 \pm 2.1$ & no data & $-35.1 \pm 1.1$ \\
11 & $52 \pm 5$ & $1191 \pm 498$ & $36 \pm 12$ & $-19.2 \pm 0.3$ & $-23.7 \pm 1.7$ & -32.1 & $-33.4 \pm 1.2$ \\
12 & $39 \pm 2$ & $1297 \pm 34$ & $153 \pm 21$ & $-23.1 \pm 0.3$ & $-19.1 \pm 0.6$ & -38.5 & $-31.2 \pm 0.6$ \\
13 & $23 \pm 7$ & $685 \pm 23$ & $11 \pm 2$ & $-27.5 \pm 0.5$ & $-28.5 \pm 1.0$ & -41.5 & $-39.8 \pm 1.8$ \\
14 & $21 \pm 1$ & $1545 \pm 95$ & $38 \pm 3$ & $-29.8 \pm 0.2$ & $-33.7 \pm 0.3$ & -35.7 & $-40.1 \pm 1.6$ \\
15 & $13 \pm 1$ & $152 \pm 21$ & $0^{\mathrm{a}}$ & $-33.8 \pm 1.6$ & $-43.8 \pm 0.5$ & -35.7 & $-39.0 \pm 1.4$ \\
16 & $0^{\mathrm{a}}$ & $444 \pm 63$ & $0^{\mathrm{a}}$ & $-29.0^{\mathrm{b}}$ & $-36.5 \pm 0.5$ & -46.8 & $-47.8 \pm 2.5$ \\
\hline Mean $\pm \mathrm{SD}$ & $26 \pm 24$ & $1049 \pm 760$ & $61 \pm 57$ & $-26.8 \pm 4.4$ & $-26.7 \pm 8.1$ & $-36.6 \pm 6.9$ & $-37.7 \pm 6.3$ \\
\hline
\end{tabular}

a Below the detection limit of about $10 \mu \mathrm{M}$;

b Single determination from pooled triplicates because of too low acetate concentration;

${ }^{\mathrm{c}}$ determination was not possible because of too low acetate concentration.

$\delta^{13} \mathrm{C}$ of $\mathrm{CO}_{2}$ and of newly formed $\mathrm{CH}_{4}$-mc (Table 2). Values of $\alpha_{\mathrm{CO}_{2}, \mathrm{CH}_{4}}$ ranged between 1.050 and 1.092 (average 1.075).

At the end of incubation, the concentrations of acetate and other fatty acids were analyzed. Acetate concentrations increased during incubation in the presence of $\mathrm{CH}_{3} \mathrm{~F}$, as acetoclastic methanogenesis was inhibited (Table 3 ). In the uninhibited control, however, acetate concentrations were very low (generally $<70 \mu \mathrm{M}$ ), often close to or below the detection limit $(10 \mu \mathrm{M})$. The acetate accumulated in the presence of $\mathrm{CH}_{3} \mathrm{~F}$ was most probably due to microbial acetate formation, while that in the absence of $\mathrm{CH}_{3} \mathrm{~F}$ was the residual acetate after microbial acetate consumption, most likely by acetoclastic methanogens. Propionate was also detected in most sediments, albeit only in the presence of $\mathrm{CH}_{3} \mathrm{~F}$ and only at concentrations that were on the average about $6 \%$ of those of acetate (Table 3). Furthermore, isovalerate was detected in 7 and butyrate in 3 out of 16 lake sediments, but only in the presence of $\mathrm{CH}_{3} \mathrm{~F}$ and with concentrations of just about $40 \mu \mathrm{M}$ and $30 \mu \mathrm{M}$, respectively (data not shown). The $\delta^{13} \mathrm{C}$ of total acetate and the methyl group of acetate was determined at the end of incubation in the absence and presence of $\mathrm{CH}_{3} \mathrm{~F}$ (Table 3). However, only values of $\delta^{13} \mathrm{C}_{\mathrm{ac}-\text { methyl }}$ in the presence of $\mathrm{CH}_{3} \mathrm{~F}$ were obtained from all the incubations, since acetate concentrations were sufficiently high under these conditions. In the absence of $\mathrm{CH}_{3} \mathrm{~F}$, the triplicate acetate samples had to be pooled to obtain sufficient acetate for analysis of $\delta^{13} \mathrm{C}_{\mathrm{ac}-\text { methyl. The }} \delta^{13} \mathrm{C}$ values of total acetate across all the different lake sediments $(-26.8 \%$ o $)$ were similar in the presence $(-26.7 \%$ ) and the absence $(-26.8 \%$ o $)$ of $\mathrm{CH}_{3} \mathrm{~F}$, but individual lake sediments had both lower and higher $\delta^{13} \mathrm{C}$ values (Table 3 ). The $\delta^{13} \mathrm{C}$ values of acetatemethyl were generally by about $10 \%$ lower than those of total acetate, both in the presence and absence of $\mathrm{CH}_{3} \mathrm{~F}$. Individual lake sediments, however, exhibited both higher and lower $\delta^{13} \mathrm{C}$ values when $\mathrm{CH}_{3} \mathrm{~F}$ was added (Table 3 ).

We also used the sediment samples to analyze the abundance, diversity and composition of the microbial community by using quantitative PCR and T-RFLP of the genes coding for the ribosomal rRNA of archaea and bacteria and of the $m c r A$ gene coding for a subunit of the methylcoenzyme $M$ reductase, the key enzyme of methanogenic archaea. The numbers of archaea and bacteria (given as 16S rRNA gene copies) are shown in Table 4. In T-RFLP analysis a total of 17, 109, and 37 different terminal restriction fragments (T-RFs) of archaeal 16S rRNA genes, bacterial 16S rRNA genes and $m c r A$ genes, respectively, were detected. On the average 9,29 , and 10, respectively, of these different T-RFs were found in each individual lake sediment. Thus, the richness of T-RFs in the combined lake sediments was larger than in the individual ones. The values of richness $(S)$, Shannon diversity index $(H)$, and evenness $(E)$ for the different lake sediments and genes are summarized in Table 5. 
Table 4. Copy numbers of bacterial and archaeal 16S rRNA genes and relative abundance of the most dominant archaeal T-RFs, putatively representing different methanogenic phyla, i.e., Methanobacteriales (92 bp), Methanosarcinaceae (186bp), Methanosaetaceae (284 bp), Methanomicrobiales or Methanocellales (393 bp); mean \pm SE, $n=3$. Details of lake sites are explained in Table 1.

\begin{tabular}{lllllll}
\hline Lake sites & Bacteria gdw $^{-1}$ & Archaea gdw $^{-1}$ & $92 \mathrm{bp} \mathrm{( \% )}$ & $186 \mathrm{bp} \mathrm{( \% )}$ & $284 \mathrm{bp} \mathrm{( \% )}$ & $393 \mathrm{bp}(\%)$ \\
\hline 1 & $(1.5 \pm 0.6) \times 10^{8}$ & $(1.5 \pm 0.7) \times 10^{8}$ & $22.3 \pm 2.5$ & $20.0 \pm 1.2$ & $14.3 \pm 1.0$ & $30.5 \pm 0.6$ \\
2 & $(2.6 \pm 0.7) \times 10^{8}$ & $(1.8 \pm 0.5) \times 10^{8}$ & $28.1 \pm 4.6$ & $12.7 \pm 1.1$ & $20.1 \pm 0.1$ & $26.0 \pm 1.2$ \\
3 & $(4.0 \pm 1.3) \times 10^{7}$ & $(1.5 \pm 0.2) \times 10^{7}$ & $23.2 \pm 0.4$ & $7.6 \pm 0.6$ & $28.5 \pm 0.7$ & $27.7 \pm 1.4$ \\
4 & $(6.7 \pm 0.5) \times 10^{8}$ & $(6.2 \pm 0.7) \times 10^{8}$ & $33.1 \pm 1.5$ & $19.5 \pm 0.5$ & $21.4 \pm 0.7$ & $20.9 \pm 0.4$ \\
5 & $(4.4 \pm 1.7) \times 10^{8}$ & $(1.5 \pm 0.2) \times 10^{7}$ & $41.5 \pm 11.4$ & $4.5 \pm 0.0$ & $20.8 \pm 1.0$ & $15.0 \pm 3.6$ \\
6 & $(6.5 \pm 0.6) \times 10^{8}$ & $(2.7 \pm 0.5) \times 10^{7}$ & $33.2 \pm 1.3$ & $5.7 \pm 1.0$ & $17.3 \pm 2.3$ & $22.4 \pm 0.6$ \\
7 & $(6.7 \pm 1.4) \times 10^{8}$ & $(3.9 \pm 1.1) \times 10^{7}$ & $18.3 \pm 4.0$ & $9.3 \pm 1.7$ & $11.2 \pm 0.1$ & $38.1 \pm 3.0$ \\
8 & $(4.7 \pm 1.8) \times 10^{8}$ & $(4.5 \pm 2.2) \times 10^{7}$ & $16.3 \pm 1.7$ & $9.7 \pm 0.2$ & $22.0 \pm 1.0$ & $24.6 \pm 1.8$ \\
9 & $(9.4 \pm 1.7) \times 10^{10}$ & $(5.5 \pm 0.7) \times 10^{8}$ & $8.4 \pm 0.7$ & $4.5 \pm 0.1$ & $23.0 \pm 0.9$ & $36.1 \pm 0.6$ \\
10 & $(1.4 \pm 0.2) \times 10^{11}$ & $(1.9 \pm 0.1) \times 10^{9}$ & $10.4 \pm 0.8$ & $6.1 \pm 0.3$ & $16.9 \pm 0.2$ & $35.0 \pm 0.4$ \\
11 & $(1.4 \pm 0.2) \times 10^{10}$ & $(1.1 \pm 0.2) \times 10^{8}$ & $7.5 \pm 1.7$ & $16.9 \pm 0.8$ & $13.4 \pm 0.8$ & $33.2 \pm 1.1$ \\
12 & $(1.8 \pm 0.3) \times 10^{8}$ & $(2.9 \pm 0.4) \times 10^{7}$ & $10.9 \pm 0.8$ & $35.9 \pm 0.8$ & $11.4 \pm 0.3$ & $37.2 \pm 0.5$ \\
13 & $(1.1 \pm 0.1) \times 10^{8}$ & $(5.7 \pm 0.5) \times 10^{7}$ & $7.9 \pm 0.4$ & $10.3 \pm 0.3$ & $32.7 \pm 0.9$ & $35.8 \pm 2.1$ \\
14 & $(1.0 \pm 0.3) \times 10^{8}$ & $(2.1 \pm 0.6) \times 10^{7}$ & $18.2 \pm 0.4$ & $14.5 \pm 0.4$ & $28.5 \pm 0.5$ & $22.3 \pm 0.4$ \\
15 & $(1.5 \pm 0.5) \times 10^{8}$ & $(2.6 \pm 0.4) \times 10^{8}$ & $8.3 \pm 1.0$ & $29.4 \pm 0.8$ & $12.5 \pm 0.2$ & $30.6 \pm 0.8$ \\
16 & $(7.9 \pm 1.5) \times 10^{8}$ & $(3.2 \pm 0.4) \times 10^{7}$ & $20.6 \pm 4.6$ & $2.1 \pm 0.2$ & $39.3 \pm 5.2$ & $16.0 \pm 3.6$ \\
\hline Mean $\pm \mathrm{SD}$ & $(1.6 \pm 4.0) \times 10^{10}$ & $(2.6 \pm 5.0) \times 10^{8}$ & $19.3 \pm 10.5$ & $13.0 \pm 9.4$ & $20.8 \pm 8.1$ & $28.2 \pm 7.5$ \\
\hline
\end{tabular}

Table 5. Diversity indices (species richness $S$, evenness $E$, and Shannon index $H$ ) for T-RFLP patterns of the archaeal $16 \mathrm{~S}$ rRNA, bacterial 16S rRNA and $m c r A$ genes (mean $\pm \mathrm{SE}$ ). Details of lake sites are explained in Table 1.

\begin{tabular}{l|ccc|ccc|ccc}
\hline $\begin{array}{l}\text { Lake sites } \\
\#\end{array}$ & \multicolumn{2}{|c|}{ archaeal 16S rRNA } & \multicolumn{2}{c|}{ bacterial 16S rRNA } & \multicolumn{2}{c}{$m c r A$} \\
& $S$ & $E$ & $H$ & $S$ & $E$ & $H$ & $S$ & $E$ \\
\hline 1 & $8.3 \pm 0.3$ & $0.82 \pm 0.02$ & $1.73 \pm 0.04$ & $23.0 \pm 1.2$ & $0.91 \pm 0.00$ & $2.84 \pm 0.4$ & $10.7 \pm 0.3$ & $0.69 \pm 0.00$ & $1.63 \pm 0.2$ \\
2 & $10.7 \pm 1.2$ & $0.76 \pm 0.2$ & $1.79 \pm 0.13$ & $33.7 \pm 0.9$ & $0.91 \pm 0.1$ & $3.22 \pm 0.06$ & $9.7 \pm 0.9$ & $0.69 \pm 0.01$ & $1.55 \pm 0.03$ \\
3 & $9.0 \pm 0.0$ & $0.78 \pm 0.1$ & $1.71 \pm 0.2$ & $37.0 \pm 1.5$ & $0.96 \pm 0.00$ & $3.46 \pm 0.04$ & $9.7 \pm 0.3$ & $0.70 \pm 0.00$ & $1.59 \pm 0.2$ \\
4 & $6.7 \pm 0.7$ & $0.82 \pm 0.02$ & $1.54 \pm 0.4$ & $26.3 \pm 0.3$ & $0.95 \pm 0.00$ & $3.11 \pm 0.02$ & $10.0 \pm 0.0$ & $0.67 \pm 0.00$ & $1.54 \pm 0.00$ \\
5 & $8.0 \pm 2.1$ & $0.78 \pm 0.4$ & $1.57 \pm 0.30$ & $21.0 \pm 1.0$ & $0.89 \pm 0.00$ & $2.71 \pm 0.05$ & $10.7 \pm 0.3$ & $0.79 \pm 0.1$ & $1.87 \pm 0.4$ \\
6 & $9.7 \pm 1.3$ & $0.80 \pm 0.00$ & $1.79 \pm 0.12$ & $23.3 \pm 0.3$ & $0.89 \pm 0.1$ & $2.80 \pm 0.04$ & $9.0 \pm 0.6$ & $0.83 \pm 0.2$ & $1.81 \pm 0.2$ \\
7 & $9.0 \pm 0.0$ & $0.82 \pm 0.1$ & $1.79 \pm 0.01$ & $18.0 \pm 1.0$ & $0.86 \pm 0.1$ & $2.49 \pm 0.04$ & $11.7 \pm 0.9$ & $0.82 \pm 0.2$ & $2.02 \pm 0.3$ \\
8 & $12.0 \pm 0.0$ & $0.82 \pm 0.02$ & $2.04 \pm 0.6$ & $30.0 \pm 1.5$ & $0.94 \pm 0.1$ & $3.18 \pm 0.07$ & $10.7 \pm 0.3$ & $0.84 \pm 0.1$ & $1.98 \pm 0.5$ \\
9 & $9.3 \pm 0.3$ & $0.83 \pm 0.01$ & $1.85 \pm 0.1$ & $24.7 \pm 0.9$ & $0.91 \pm 0.00$ & $2.91 \pm 0.03$ & $8.7 \pm 0.3$ & $0.87 \pm 0.1$ & $1.88 \pm 0.2$ \\
10 & $10.7 \pm 0.3$ & $0.85 \pm 0.00$ & $2.00 \pm 0.2$ & $38.0 \pm 2.9$ & $0.96 \pm 0.00$ & $3.50 \pm 0.08$ & $8.7 \pm 0.3$ & $0.81 \pm 0.01$ & $1.79 \pm 0.2$ \\
11 & $10.3 \pm 0.3$ & $0.85 \pm 0.1$ & $1.99 \pm 0.1$ & $26.7 \pm 5.4$ & $0.91 \pm 0.00$ & $2.96 \pm 0.23$ & $9.3 \pm 0.7$ & $0.82 \pm 0.01$ & $1.82 \pm 0.03$ \\
12 & $7.0 \pm 0.0$ & $0.73 \pm 0.00$ & $1.41 \pm 0.1$ & $25.0 \pm 1.5$ & $0.94 \pm 0.00$ & $3.02 \pm 0.05$ & $12.7 \pm 0.9$ & $0.86 \pm 0.01$ & $2.18 \pm 0.5$ \\
13 & $8.0 \pm 1.0$ & $0.78 \pm 0.2$ & $1.61 \pm 0.09$ & $33.0 \pm 2.1$ & $0.95 \pm 0.00$ & $3.30 \pm 0.07$ & $12.7 \pm 0.3$ & $0.75 \pm 0.1$ & $1.91 \pm 0.02$ \\
14 & $9.0 \pm 0.0$ & $0.83 \pm 0.1$ & $1.82 \pm 0.6$ & $37.0 \pm 2.3$ & $0.94 \pm 0.00$ & $3.38 \pm 0.07$ & $12.3 \pm 0.3$ & $0.82 \pm 0.00$ & $2.05 \pm 0.01$ \\
15 & $9.7 \pm 0.3$ & $0.80 \pm 0.1$ & $1.81 \pm 0.01$ & $32.3 \pm 0.7$ & $0.97 \pm 0.00$ & $3.37 \pm 0.2$ & $9.7 \pm 0.3$ & $0.88 \pm 0.00$ & $1.99 \pm 0.03$ \\
16 & $8.0 \pm 1.0$ & $0.75 \pm 0.03$ & $1.55 \pm 0.16$ & $27.0 \pm 1.5$ & $0.88 \pm 0.00$ & $2.90 \pm 0.05$ & $10.3 \pm 0.9$ & $0.82 \pm 0.01$ & $1.90 \pm 0.5$ \\
\hline Mean $\pm \mathrm{SD}$ & $9.1 \pm 1.6$ & $0.80 \pm 0.04$ & $1.75 \pm 0.18$ & $28.5 \pm 6.0$ & $0.92 \pm 0.03$ & $3.07 \pm 0.29$ & $10.4 \pm 1.2$ & $0.79 \pm 0.07$ & $1.84 \pm 0.19$ \\
\hline
\end{tabular}

The T-RFLP patterns of the different genes were also analysed by canonical correspondence analysis (Fig. 2). The TRFLP patterns of the lake sediments did not show a consistent clustering across the different genes indicating that bacterial and archaeal communities did not follow a geographical pattern. The T-RFLP patterns of the individual lakes were also not consistently correlated to one of the different vectors that indicate the chemical/physiological parameters measured, such as $\mathrm{C}_{\mathrm{org}}, \delta^{13} \mathrm{C}_{\mathrm{org}}, \mathrm{CH}_{4}$ production, abundance of archaea and bacteria, $\delta^{13} \mathrm{C}_{\mathrm{CH}_{4}}, \delta^{13} \mathrm{C}_{\mathrm{CO}_{2}}, \delta^{13} \mathrm{C}_{\mathrm{CH}_{4}-\mathrm{mc}}$,

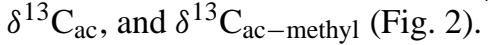



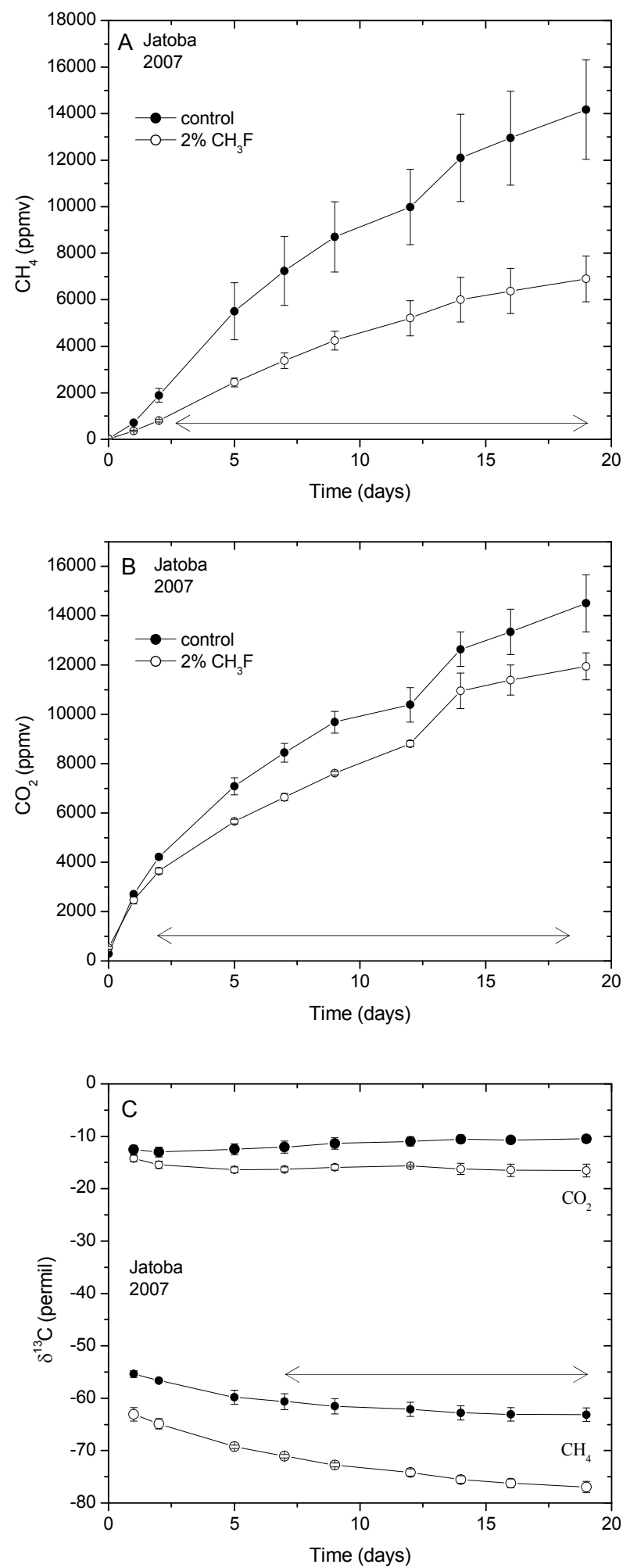

Fig. 1. Production of $\mathrm{CH}_{4}$ and $\mathrm{CO}_{2}$ in anaerobically incubated sediment of Lake Jatoba in the presence and absence of $2 \%$ methyl fluoride; (A) accumulation of $\mathrm{CH}_{4}$ in the headspace; (B) accumulation of $\mathrm{CO}_{2}$ in the headspace; (C) $\delta^{13} \mathrm{C}$ of the accumulated $\mathrm{CH}_{4}$ and $\mathrm{CO}_{2}$; average $\pm \mathrm{SE} ; n=3$. The arrows indicate the period used for averaging data for determination of production rates or average $\delta^{13} \mathrm{C}$.
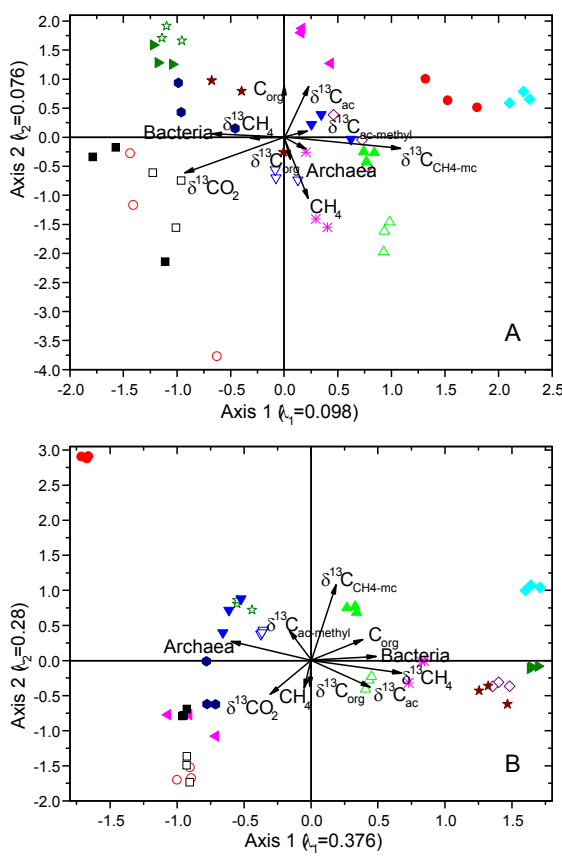

Symbol legend

$\diamond \# 1$ Arrozal

* \#2 Sinibu

$\nabla \quad \# 3$ Jatoba

\#4 Anzol de Ouro

○ \#5 Teresa

$\square$ \#6 Presa

^ \#7 Lobo

- \#8 Lake 1, 2008

\#9 Lake 1, margin

is \#10 Lake 1, central

\#11 Lake 2

\#12 Belmont

\#13 Maravilha

\#14 Laguinho

\#15 Paca

\#16 Puruzinho

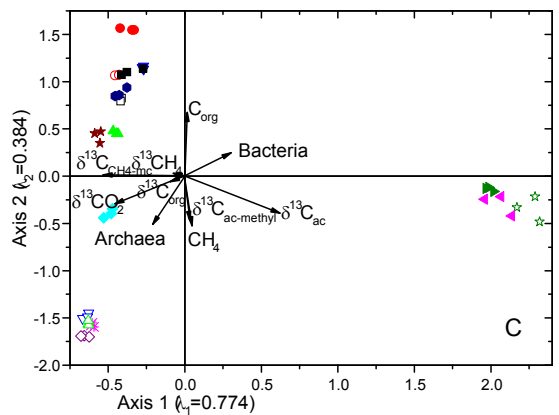

Fig. 2. Canonical correspondence analysis ordination plot for the effect of $\mathrm{C}_{\text {org }}, \delta^{13} \mathrm{C}_{\text {org }}, \mathrm{CH}_{4}$ production, abundance of archaea and bacteria, $\delta^{13} \mathrm{C}_{\mathrm{CH}_{4}}, \delta^{13} \mathrm{C}_{\mathrm{CO}_{2}}, \delta^{13} \mathrm{C}_{\mathrm{CH}_{4}-\mathrm{mc}}, \delta^{13} \mathrm{C}_{\mathrm{ac}}$, and

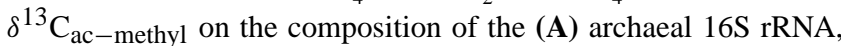
(B) bacterial 16S rRNA, and (C) $m c r A$ gene community in lake sediments, based on the relative abundances of respective T-RFs from the sediments of three replicate measurements. Symbol legend and eigenvalues of the first and second axes are included.

Most of the T-RFs in the T-RFLP patterns of archaeal 16S rRNA gene could be assigned to groups of methanogenic archaea on the basis of published clone sequences (e.g., Conrad et al., 2010b): Methanomicrobiales (84 bp); Methanobacteriales (92 bp); Methanosarcinaceae (186bp); Methanosaetaceae (284 bp); Methanomicrobiales and Methanocellales (393 bp). These methanogenic groups contributed on the average $81 \%$ to the total archaeal community (Table 4 ). 


\section{Discussion}

Incubation experiments with samples from 16 different lake sediments in tropical Brazil allowed estimating the activity and isotope fractionation involved in $\mathrm{CH}_{4}$ production from organic matter. In particular, the data gave insight into the control of $\mathrm{CH}_{4}$ production rate, the role of the microbial community, the path of $\mathrm{CH}_{4}$ production, and the carbon isotope fractionation during acetate production.

\subsection{Control of $\mathrm{CH}_{4}$ and $\mathrm{CO}_{2}$ production}

The rates of $\mathrm{CH}_{4}$ in the different lake sediments linearly increased with the content of $\mathrm{C}_{\text {org }}$ (Fig. 3a). The lake sediments with the highest organic carbon contents were from the Pantanal. Production rates of $\mathrm{CH}_{4}$ almost doubled (relative slope $=0.83$ ) with doubling of the organic matter content. These data show that organic matter content was a ratelimiting factor for $\mathrm{CH}_{4}$ production. This is a reasonable conclusion, since the initial mobilization of organic substances is believed to be the rate-limiting step for further degradation and eventual $\mathrm{CH}_{4}$ production (Billen, 1982). The dependency on organic matter content furthermore indicates that the $\mathrm{CH}_{4}$ production process was under quasi steady state conditions. This is a reasonable conclusion, since acetate, or other organic intermediates apparently did not accumulate during the incubation but were below or close to the detection limit of the analysis. Acetate only accumulated, when its consumption by acetoclastic methanogens was inhibited with $\mathrm{CH}_{3} \mathrm{~F}$. The observation that $\mathrm{CH}_{4}$ production scales with the sediment organic matter content is in agreement with an analysis of lake characteristics determining $\mathrm{CH}_{4}$ emission by Bastviken et al. (2004). These authors found that lake area, along with total phosphorous and dissolved organic carbon concentrations were the most useful variables for describing methane emissions on a global basis. Ebullition is the most likely fate $(>50 \%)$ of the produced $\mathrm{CH}_{4}$ especially in relatively shallow lakes. In lakes of the Pantanal, ebullition was found to account on the average for $91 \%$ of the total $\mathrm{CH}_{4}$ flux (Bastviken et al., 2010). Generally, only a small percentage of the total organic matter present in anoxic sediments is used up for production of $\mathrm{CH}_{4}$ and $\mathrm{CO}_{2}$. Therefore, total sediment organic matter is only a proxy for the organic matter that is actually available for microorganisms and eventually degraded on the time scale used for our experiments. However, in the Brazilian lake sediments, sediment $\mathrm{C}_{\text {org }}$ was apparently a good predictor for potential $\mathrm{CH}_{4}$ production.

Production rates of gaseous $\mathrm{CO}_{2}$ also increased linearly with organic matter content (data not shown). The production rates of gaseous $\mathrm{CO}_{2}$ versus $\mathrm{CH}_{4}$ were almost proportional to each other $\left(\mathrm{y}=0.74+0.77 \mathrm{x} ; r^{2}=0.83 ; P<\right.$ $0.0001)$ but not quite equimolar. According to

$\mathrm{C}_{6} \mathrm{H}_{12} \mathrm{O}_{6} \rightarrow 3 \mathrm{CO}_{2}+3 \mathrm{CH}_{4}$ complete degradation of organic matter should actually produce equimolar amounts of $\mathrm{CO}_{2}$ and $\mathrm{CH}_{4}$ (i.e., relative slope $=1.0$ ). However, the measured $\mathrm{CO}_{2}$ production rates covered only the gaseous portion of $\mathrm{CO}_{2}$ in the incubations. Rates of total $\mathrm{CO}_{2}$ production were determined by accounting for dissolved $\mathrm{CO}_{2}$ and bicarbonate, which were calculated from Henry's law, the $\mathrm{pH}$ and the bicarbonate dissociation constant. In fact, total $\mathrm{CO}_{2}$ production rates were almost two times higher than $\mathrm{CH}_{4}$ production rates (Fig. 3b). Such behaviour is frequently observed in acidic bogs (Galand et al., 2010; Heitmann et al., 2007; Keller et al., 2009; Yavitt and Seidmann-Zager, 2006), but also in lake sediments (Conrad et al., 2010a, 2010b). It has been explained by the assumption that organic substances may act to some extent as electron acceptors for oxidation of organic matter, so that Eq. (6) is not rigorously valid. Nevertheless, this effect seemed to be rather small when considering the range of $\mathrm{CH}_{4}$ and $\mathrm{CO}_{2}$ production in the different lake sediments investigated.

Not only the production rates of $\mathrm{CH}_{4}$ and $\mathrm{CO}_{2}$ were related to the organic matter content of the sediment, also the $\delta^{13} \mathrm{C}$ of $\mathrm{CH}_{4}, \mathrm{CO}_{2}$ (and also acetate, see discussion below) were all correlated to the $\delta^{13} \mathrm{C}$ of organic matter (Fig. 4). This is reasonable since all are eventually produced from organic matter. However, the $\delta^{13} \mathrm{C}$ values were neither correlated with the content of organic matter nor the production rates of $\mathrm{CH}_{4}$ and $\mathrm{CO}_{2}$.

\subsection{Role of the microbial community}

The numbers of archaea (given as 16S rRNA gene copies) were generally one order of magnitude lower than those of the bacteria, similarly as observed in other lake sediments (Chan et al., 2005; Koizumi et al., 2003; Schwarz et al., 2007a; Zepp-Falz et al., 1999). Both numbers were correlated with each other (Fig. 5a). Production rates of $\mathrm{CH}_{4}$ increased linearly with the logarithm of numbers of archaea (Fig. 5b) and bacteria (not shown). This is plausible since microorganisms are catalyzing the biogeochemical processes, including degradation of organic matter to $\mathrm{CO}_{2}$ and $\mathrm{CH}_{4}$. Vice versa, the transformation of organic matter provides the energy for growth and maintenance of the microorganisms. Production rates of $\mathrm{CH}_{4}$ more than quadrupled (relative slope $=4.4$ ) when the abundance of archaea increased by an order of magnitude. The increase of microbial numbers with $\mathrm{CH}_{4}$ production rates is reasonable since microorganisms can proliferate when energy supply increases, i.e. the rate of methanogenic organic matter degradation increases. The number of methanogenic archaea that can be maintained by a particular $\mathrm{CH}_{4}$ production rate can be calculated from the microbial maintenance requirement which at $25^{\circ} \mathrm{C}$ is constant at $4.5 \mathrm{~kJ} \mathrm{~h}^{-1} \mathrm{C}-\mathrm{mol}^{-1}$ biomass (Tijhuis et al., 1993). Using this constant parameter, theoretical calculations indicate that a $\mathrm{CH}_{4}$ production rate of $100 \mathrm{nmol} \mathrm{h}^{-1} \mathrm{~g}^{-1}$ could maintain about $6 \times 10^{7} \mathrm{~g}^{-1}$ methanogenic archaea (Conrad, 

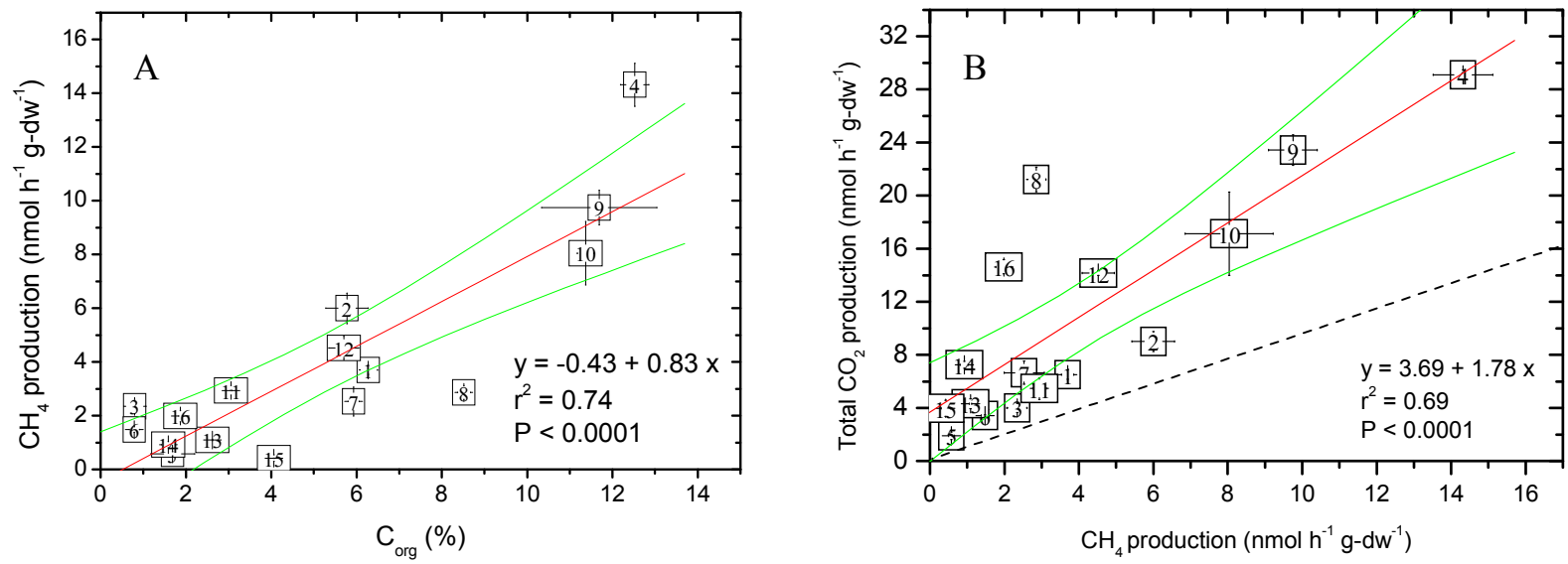

Fig. 3. Linear regression of production rates of $\mathrm{CH}_{4}$ and $\mathrm{CO}_{2}$ determined in 16 different lake sediments; $(\mathbf{A}) \mathrm{CH}_{4}$ production against the content of $\mathrm{C}_{\mathrm{org}}$; (B) Total $\mathrm{CO}_{2}$ production against $\mathrm{CH}_{4}$ production; numbers of data points refer to the identity of the lake sediment as shown in Table 1; error bars give standard errors of $n=3$; the result of linear regression is given by a thin straight line with small-dotted curved lines as 95\% confidence limit; the dashed straight line in $(\mathbf{B})$ indicates the 1:1 proportionality line between the two production rates.

2007). These calculations are based on the assumption that $1 \mathrm{C}$-mol microbial biomass is equivalent to $1.4 \times 10^{14} \mathrm{mi}-$ crobial cells, a value which may be disputed because of the large range of possible cell sizes of archaea. In the Brazilian lakes we found between $1 \times 10^{7}$ and $2 \times 10^{9}$ copies of archaeal ribosomal genes per gram dry sediment (Fig. 5). Since methanogenic archaea typically contain 3 ribosomal gene copies per cell (Klappenbach et al., 2001), the lake sediments correspondingly contained between $3 \times 10^{6}$ and $7 \times 10^{8}$ methanogenic archaea per gram sediment. However, the $\mathrm{CH}_{4}$ production rates were only between 0.5 and 14 nmol h${ }^{-1} \mathrm{~g}^{-1}$, thus theoretically allowing the maintenance of about only $3 \times 10^{5}$ to $8 \times 10^{6} \mathrm{~g}^{-1}$ methanogens, which is 1-2 orders of magnitude lower than the actually measured values. This is a large discrepancy even when considering uncertainties in the theoretical calculation. We hypothesize that much of the microbial DNA, i.e., the ribosomal genes detected, may be preserved in dead cells and no longer take part in the metabolism and substrate turnover in the lake sediment.

If this is true, the analysis of DNA and of genes in the sediment would not reflect the active microbial community but mainly give an impression about the history of microbial activity. In sediments, in which metabolism is in a stable steady state, these two aspects would not be much different, but sediments which undergo seasonal and daily changes might well result in strong differences. For the Brazilian lake sediments we have to expect the latter case, since these lakes are part of river floodplains which exhibit flooding pulses.

Such effect was probably the reason why sediment taken from the central of Lake 1 in 2008 (\#8) behaved completely different from samples taken in 2007 (\#10). Sample \#8 was taken at a time when the lake was just at the beginning of the wet season, while the samples \#9-11 were taken during the time when water from the Paraguay River inundated the lakes. At this time, the sulfate content of the sediment (\#8) was much larger than in $\# 10$, and $\mathrm{CH}_{4}$ production exhibited a lag phase, probably because sulfate reducers outcompeted methanogens.

Analysis of the relative composition of the communities of bacteria, archaea and $m c r A$-containing methanogens showed quite diversity in each of the different Brazilian lake sediments. The Shannon index of bacterial community patterns ranged between 2.5 and 3.9, whereas that for archaea and methanogens was a bit lower between 1.4 and 2.0 (Table 5). The evenness of the bacterial community patterns were generally higher than 0.67 and reached maximum values of 0.97 . These diversity indices should not be taken as absolute numbers, since molecular fingerprinting techniques only reveal the relatively abundant taxa but cannot cover the less common microbes (Bent and Forney, 2008). However, the indices and the T-RFLP patterns can be compared across the different lakes. The comparison shows that the composition of the communities was different for each lake and exhibited no pattern with respect to geographical location, organic matter content, microbial abundance, activity or isotope fractionation. The composition patterns were also different with respect to bacteria, archaea and methanogens. Neither of the diversity indices exhibited a significant correlation to the $\mathrm{CH}_{4}$ production rates. The failure to detect a microbial community pattern that would be related to the microbial functionality of the lake sediments may have several reasons: (1) the number of lake sediments tested was still too limited to detect such a relationship; (2) such a relationship does not exist on the level of microbial genes detected but might exist on the level of microbial transcripts (expression of genes) or microbial proteins (transcription and translation of genes); (3) such a relationship is not visible on the level 

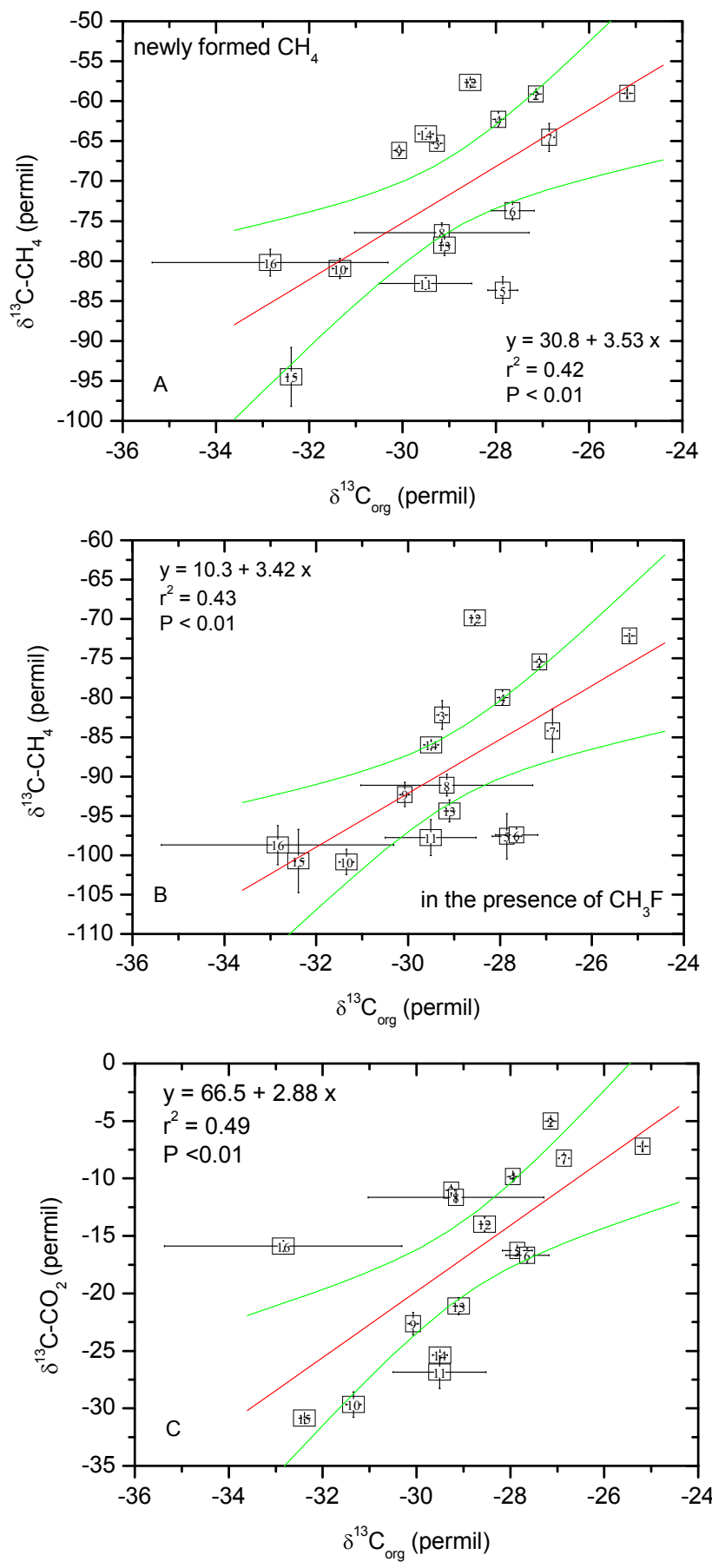

Fig. 4. Linear regression of the $\delta^{13} \mathrm{C}$ of $\mathrm{CH}_{4}$ and $\mathrm{CO}_{2}$ against the $\delta^{13} \mathrm{C}$ of sediment organic matter determined in 16 different lake sediments; (A) average $\delta^{13} \mathrm{C}$ of newly formed $\mathrm{CH}_{4}$ in the absence of $\mathrm{CH}_{3} \mathrm{~F}$; (B) average $\delta^{13} \mathrm{C}$ of newly formed $\mathrm{CH}_{4}$ in the presence of $\mathrm{CH}_{3} \mathrm{~F}\left(=\delta^{13} \mathrm{C}_{\mathrm{CH}_{4}-\mathrm{mc}}\right) ;(\mathbf{C})$ average $\delta^{13} \mathrm{C}$ of gaseous $\mathrm{CO}_{2}$; other explanations see Fig. 3 .

of global genes, such as ribosomal RNA or $m c r A$ genes, but only when targeting genes that allow differentiating between different peculiar functions; (4) there is no such relationship at all, since diverse microbial species can replace each other to fulfil a particular functionality.

Although the data give an impression of the diversity of the bacterial, archaeal and methanogenic communities, they do not give insight into their phylogenetic and taxonomic structure. Such information can usually only be obtained after extensive sequencing of $16 \mathrm{~S}$ rRNA and mcrA genes. The T-RFLP patterns of bacterial 16S rRNA and methanogenic $m c r A$ genes are usually complex, and affiliation of phylogenetic groups to individual T-RFs is difficult without sequence information from the samples studied. However, such affiliation may be feasible with respect to archaeal TRFLP patterns, which generally show a highly reproducible and relatively simple pattern (e.g., Conrad et al., 2010b). Thus, we are confident that the methanogenic groups identified by T-RFLP analysis of archaeal 16S rRNA genes (Table 4) are trustworthy. The methanogens comprised both putatively acetoclastic methanogens (Methanosarcinaceae and Methanosaetaceae) and hydrogenotrophic methanogens (all the groups except Methanosaetaceae). The family Methanosarcinaceae may also comprise species that are potentially methylotrophic (e.g., consuming methanol). However, the relative abundance of the different methanogenic groups in the different lake sediments did not correlate with biogeochemical characteristics (compare 4.3 below).

\subsection{Path of $\mathrm{CH}_{4}$ production}

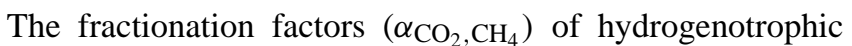
methanogenesis, which were calculated from $\delta^{13} \mathrm{C}$ of $\mathrm{CO}_{2}$ and $\mathrm{CH}_{4}$ in the presence of $\mathrm{CH}_{3} \mathrm{~F}$, did not reveal correlation with any other variable in the individual lake sediments, e.g., $\mathrm{C}_{\text {org }}$ or $\delta^{13} \mathrm{C}_{\text {org }}$. However, the $\delta^{13} \mathrm{C}$ of $\mathrm{CH}_{4}$ and $\mathrm{CO}_{2}$ were all correlated to each other and to the $\delta^{13} \mathrm{C}$ or organic matter (Fig. 4). The relative increase of $\delta^{13} \mathrm{C}_{\mathrm{CH}_{4}}$ and $\delta^{13} \mathrm{C}_{\mathrm{CO}_{2}}$ was larger than that of $\delta^{13} \mathrm{C}_{\text {org }}$ with slopes of 2.9-3.5 (Fig. 4). On the average, the $\delta^{13} \mathrm{C}$ of newly formed $\mathrm{CH}_{4}$ was $43 \%$ o lower and that of $\mathrm{CO}_{2}$ was $12 \%$ larger than $\delta^{13} \mathrm{C}_{\text {org }}$. These data show that the $\delta^{13} \mathrm{C}$ of $\mathrm{CH}_{4}$ and $\mathrm{CO}_{2}$ were not only determined by the $\delta^{13} \mathrm{C}_{\text {org }}$ but also by the fractionation during the degradation process. In the presence of $\mathrm{CH}_{3} \mathrm{~F}$, the differ-

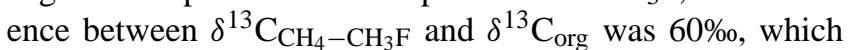
is about $17 \%$ more than with $\delta^{13} \mathrm{C}_{\mathrm{CH}_{4}}$ in the absence of $\mathrm{CH}_{3} \mathrm{~F}$. This increase is due to the inhibition of acetoclastic methanogenesis by $\mathrm{CH}_{3} \mathrm{~F}$ and the subesequently exclusive formation of $\mathrm{CH}_{4}$ by hydrogenotrophic methanogenesis, which exhibits a larger fractionation factor than acetoclastic methanogenesis. The difference of $60 \%$ lower $\mathrm{CH}_{4}$ and $12 \%$ o larger $\mathrm{CO}_{2}$ results in a difference of about $72 \%$ between $\delta^{13} \mathrm{C}$ of $\mathrm{CO}_{2}$ and of hydrogenotrophically formed $\mathrm{CH}_{4}$, which corresponds to $\alpha_{\mathrm{CO}_{2}, \mathrm{CH}_{4}}=1.075$ determined from the measured $\delta^{13} \mathrm{C}_{\mathrm{CO}_{2}}$ and $\delta^{13} \mathrm{C}_{\mathrm{CH}_{4}}$ measured in the presence of $\mathrm{CH}_{3} \mathrm{~F}$. Thus, fractionation had the larger effect on $\delta^{13} \mathrm{C}_{\mathrm{CO}_{2}}$ and $\delta{ }^{13} \mathrm{C}_{\mathrm{CH}_{4}}$ than the $\delta^{13} \mathrm{C}_{\mathrm{org}}$. The fractionation factors $\left(\alpha_{\mathrm{CO}_{2}, \mathrm{CH}_{4}}\right)$ for the 16 different tropical lake sediments 

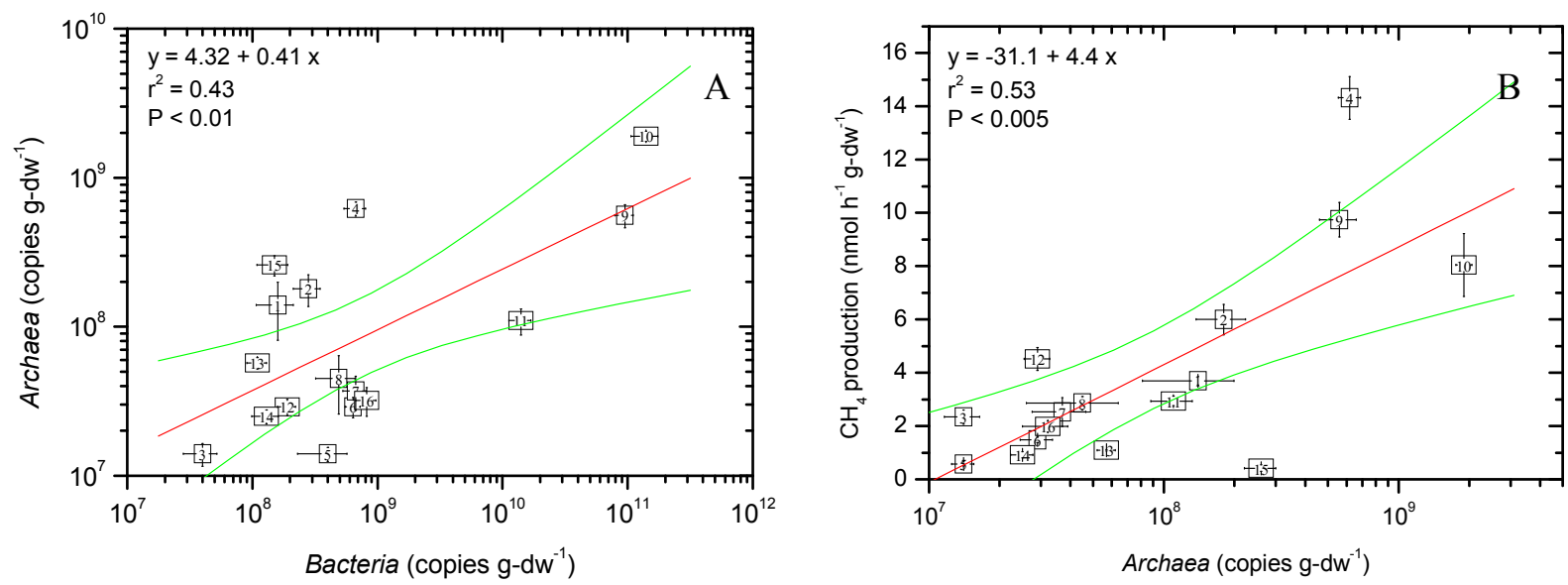

Fig. 5. Linear regression of (A) numbers of archaea against numbers of bacteria in the sediment (given as copies of the 16S rRNA gene); (B) $\mathrm{CH}_{4}$ production rates against numbers of archaea; other explanations see Fig. 3.
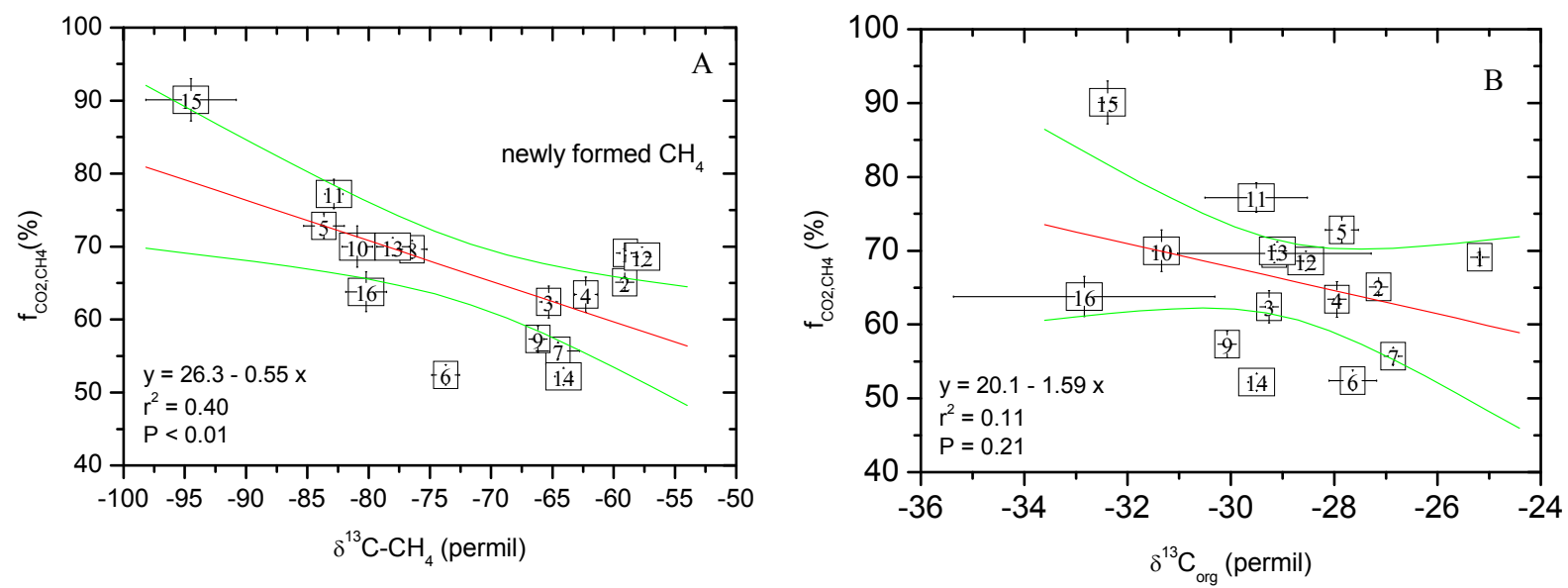

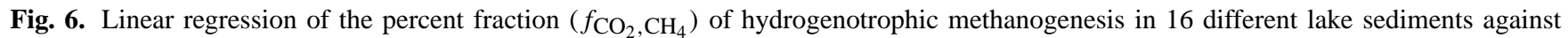

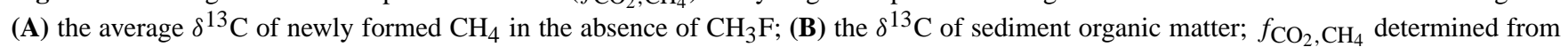
Eq. (4) using $\varepsilon_{\mathrm{ac}, \mathrm{CH}_{4}}=0$; other explanations see Fig. 3.

(Table 2) ranged between 1.050 and 1.092 , also covering the $\alpha_{\mathrm{CO}_{2}, \mathrm{CH}_{4}}$ values of about 1.085 recently determined for two lake sediments in Amazonia (Conrad et al., 2010b). These data are consistent with literature data on aquatic sediments in which the energy provided by $\mathrm{H}_{2}$ is limiting $\mathrm{CH}_{4}$ production (Penning et al., 2005; Takai et al., 2008; Valentine et al., 2004).

The values of $\delta^{13} \mathrm{C}$ of newly formed $\mathrm{CH}_{4}$ were used for

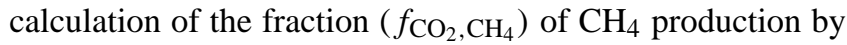
hydrogenotrophic methanogenesis using Eq. (4). The equation uses $\delta^{13} \mathrm{C}$ of $\mathrm{CH}_{4}$, of $\mathrm{CH}_{4}-\mathrm{mc}$ and of $\mathrm{CH}_{4}$-ma, the latter being the $\mathrm{CH}_{4}$ formed from acetoclastic methanogenesis. The values of $f_{\mathrm{CO}_{2}, \mathrm{CH}_{4}}$ are summarized in Fig. 6 and Fig. 7. First, it was assumed that $\delta^{13} \mathrm{C}_{\mathrm{CH}_{4}-\text { ma }}$ was identical to the $\delta^{13} \mathrm{C}$ of the acetate-methyl $\left(\delta^{13} \mathrm{C}_{\mathrm{ac}-\text { methyl }}\right)$. This assumption means that acetate-methyl was not further fractionated dur- ing acetoclastic methanogenesis Eq. (5), which is the case if acetate is consumed as rapidly as it is produced. This was most likely the case, since acetate concentrations were very low in all the lake sediments studied and only increased when acetoclastic methanogenesis was inhibited by $\mathrm{CH}_{3} \mathrm{~F}$. Values of $f_{\mathrm{CO}_{2}, \mathrm{CH}_{4}}$ were generally higher than $50 \%$ (50-90\%) demonstrating that hydrogenotrophic methanogenesis was more important than acetoclastic methanogenesis in all the lake sediments. The error imposed by neglecting a putative fractionation during formation of $\delta^{13} \mathrm{C}_{\mathrm{CH}_{4}-\text { ma }}$ is relatively small since the theoretical fractionation factor for the conversion of acetate-methyl to $\mathrm{CH}_{4}$ is at the maximum $\alpha_{\mathrm{ac}, \mathrm{CH}_{4}}=$ $1.025\left(\varepsilon_{\mathrm{ac}, \mathrm{CH}_{4}}=-25 \%\right)$ when Methanosarcina species are the active methanogens (Gelwicks et al., 1994; Goevert and Conrad, 2009) or $\alpha_{\mathrm{ac}, \mathrm{CH}_{4}}=1.010\left(\mathrm{ac}, \mathrm{CH}_{4}=-10 \%\right.$ ) when Methanosaeta species are the active methanogens (Penning 

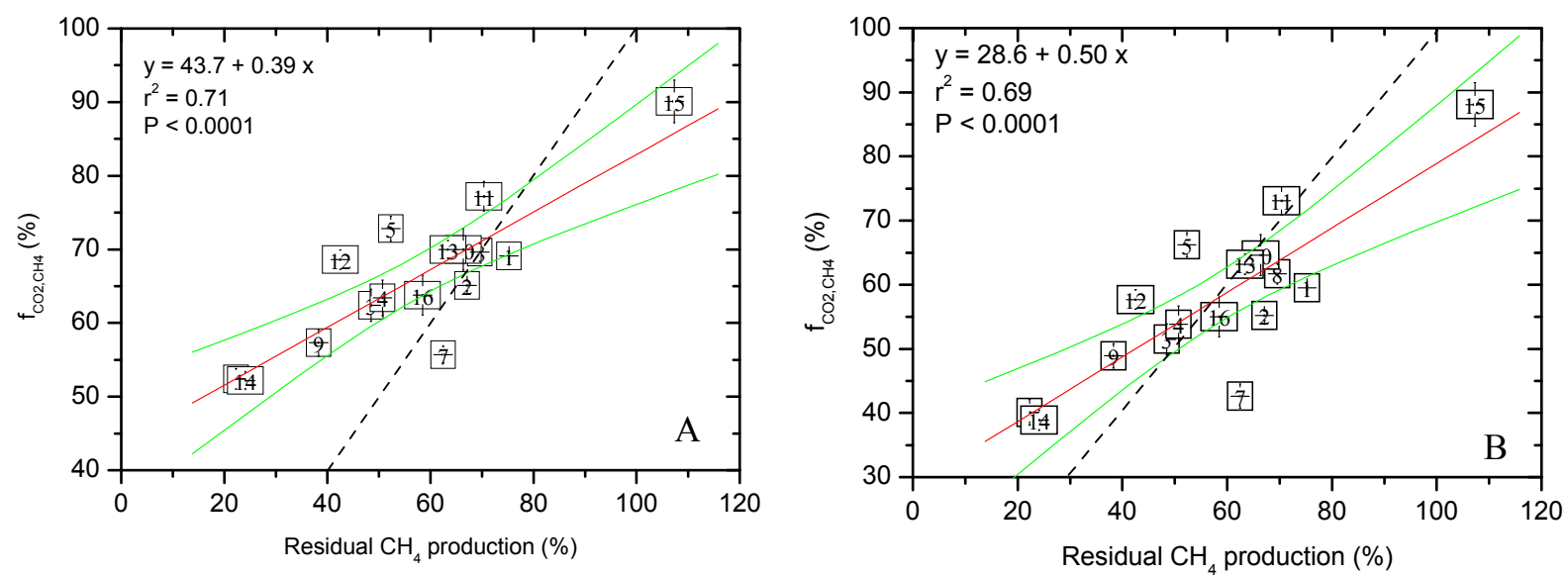

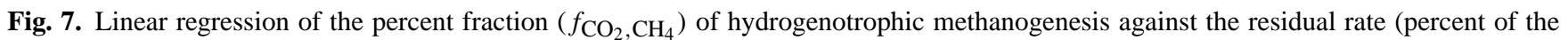
uninhibited rate) of $\mathrm{CH}_{4}$ production measured in the presence of $\mathrm{CH}_{3} \mathrm{~F}$ using $(\mathbf{A}) \varepsilon_{\mathrm{ac}}, \mathrm{CH}_{4}=0$, and $(\mathbf{B}) \varepsilon_{\mathrm{ac}}, \mathrm{CH}_{4}=-10 \%$; other explanations see Fig. 3.

et al., 2006; Valentine et al., 2004). The assumption that $\delta^{13} \mathrm{C}_{\mathrm{CH}_{4}-\text { ma }}$ is by $10 \%$ smaller than $\delta^{13} \mathrm{C}_{\mathrm{ac}-\text { methyl }}$ results in values of $f_{\mathrm{CO}_{2}, \mathrm{CH}_{4}}$ ranging between $40 \%$ and $90 \%$ (Fig. $7 \mathrm{~b}$ ). The $f_{\mathrm{CO}_{2}, \mathrm{CH}_{4}}$ values showed a significant negative correlation with the $\delta^{13} \mathrm{C}_{\mathrm{CH} 4-\mathrm{mc}}$ (Fig. 6a), which was expected from Eq. (4), but no significant correlation with $\delta^{13} \mathrm{C}_{\mathrm{ac}-\text { methyl }}$ $\left(y=74.5+0.26 x ; r^{2}=0.05 ; P=0.41\right)$. The $f_{\mathrm{CO}_{2}, \mathrm{CH}_{4}}$ values also showed no correlation with $\alpha_{\mathrm{CO}_{2}, \mathrm{CH}_{4}}\left(r^{2}=0\right)$ and $\mathrm{CH}_{4}$ production rates $\left(r^{2}=0.03\right)$, and the decreasing tendency with $\delta^{13} \mathrm{C}_{\text {org }}\left(r^{2}=0.11\right)$ was not significant (Fig. 6b).

The values of $f_{\mathrm{CO}_{2}}, \mathrm{CH}_{4}$ also correlated positively, but not proportionally, with the residual $\mathrm{CH}_{4}$ production after inhibition of acetoclastic methanogenesis by $\mathrm{CH}_{3} \mathrm{~F}$ (Fig. 7). Such correlation is expected, as the residual rates are the $\mathrm{CH}_{4}$ production rates diminished by those of acetoclastic methanogenesis and should be equal to the rates of hy-

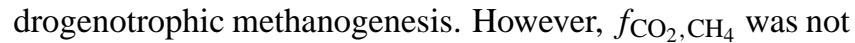
proportional to the residuals and increased with a relative slope of much smaller than one. The result was principally the same whether fractionation during acetclastic methanogenesis was assumed to be zero or $\varepsilon_{\mathrm{ac}, \mathrm{CH}_{4}}=-10$ (Fig. 7). Therefore, we have to assume that $\mathrm{CH}_{3} \mathrm{~F}$ inhibited not only acetoclastic methanogenesis but also to some degree hydrogenotrophic methanogenesis. Previous studies had shown that hydrogenotrophic methanogenesis is indeed sensitive to $\mathrm{CH}_{3} \mathrm{~F}$ if applied at a too high concentration (Conrad and Klose, 1999). It is hardly possible to optimize inhibition by $\mathrm{CH}_{3} \mathrm{~F}$ for each individual sediment, in particular, since quite small changes in $\mathrm{CH}_{3} \mathrm{~F}$ concentration can result in change of the inhibition pattern. In the present study we found that the unspecific inhibition of hydrogenotrophic methanogenesis became increasingly larger in those lake sediments that had

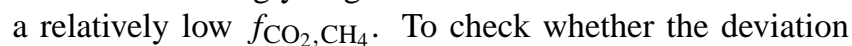

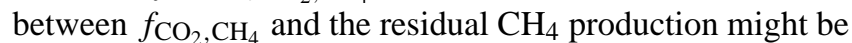
due to interference by methylotrophic methanogenesis, the difference between the two data was plotted against the relative abundance of the Methanosarcinaceae (Table 5), which may contain methylotrophic species, but the plot showed no significant correlation $\left(r^{2}=0.02\right)$.

The determination of $f_{\mathrm{CO}_{2}, \mathrm{CH}_{4}}$ assumed that the $\mathrm{CH}_{4}$ produced in the presence of $\mathrm{CH}_{3} \mathrm{~F}$ was exclusively due to hydrogenotrophic methanogenesis, as acetoclastic methanogenesis was completely inhibited (Conrad, 2005). Previous studies with other lake sediments have shown that this assumption is robust (Conrad et al., 2007, 2009, 2010b). The observation of accumulation of some propionate in addition to acetate indicates that secondary fermentation was also partially inhibited, most probably by accumulating acetate and $\mathrm{H}_{2}$ causing thermodynamic inhibition (Rothfuss and Conrad, 1993). Although $\mathrm{H}_{2}$ was not measured, we assume increased $\mathrm{H}_{2}$ partial pressures in the presence of $\mathrm{CH}_{3} \mathrm{~F}$ due to partially inhibition of hydrogenotrophic methanogenesis (Conrad et al., 2010b).

It is noteworthy that the determined values of $f_{\mathrm{CO}_{2}, \mathrm{CH}_{4}}$ were relatively large, independently of the $\varepsilon_{\mathrm{ac}, \mathrm{CH}_{4}}$ chosen. This observation is consistent with determinations in other lake sediments (Conrad, 1999; Conrad et al., 2009; 2010a; 2010 b), but cannot be explained by the complete degradation of organic matter according to Eq. (6), since

$$
\begin{aligned}
& \mathrm{C}_{6} \mathrm{H}_{12} \mathrm{O}_{6}+2 \mathrm{H}_{2} \mathrm{O} \rightarrow 2 \mathrm{CH}_{3} \mathrm{COOH}+2 \mathrm{CO}_{2}+4 \mathrm{H}_{2} \\
& 2 \mathrm{CH}_{3} \mathrm{COOH} \rightarrow 2 \mathrm{CH}_{4}+2 \mathrm{CO}_{2} \\
& 4 \mathrm{H}_{2}+\mathrm{CO}_{2} \rightarrow \mathrm{CH}_{4}+2 \mathrm{H}_{2} \mathrm{O}
\end{aligned}
$$

where hydrogenotrophic methanogenesis can only achieve a maximum contribution of $33 \%$ (Conrad, 1999). Conceivable explanations are (1) that organic matter in the lake sediments is incompletely degraded with the preferential production of $\mathrm{H}_{2}$ and the accumulation of residual organic substances having a higher oxidation state than the original $\mathrm{C}_{\text {org }}$. 

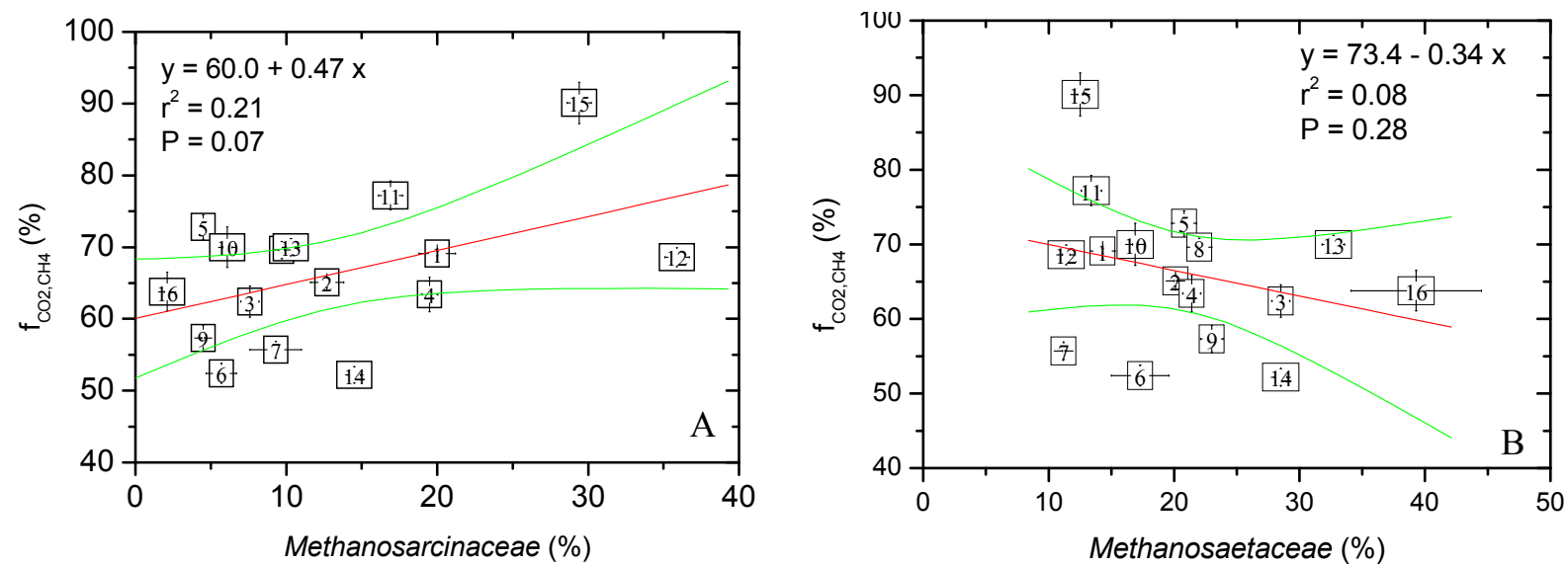

Fig. 8. Linear regression of the percent fraction $\left(f_{\mathrm{CO}_{2}, \mathrm{CH}_{4}}\right)$ of hydrogenotrophic methanogenesis against the relative (percent) abundance of (A) Methanosarcinceae (186 bp) and (B) Methanosaeta spp. (284 bp) in the community of archaea (see Table 4) determined in 16 different lake sediments; $f_{\mathrm{CO}_{2}, \mathrm{CH}_{4}}$ determined from Eq. (4) using $\varepsilon_{\mathrm{ac}, \mathrm{CH}_{4}}=0$; other explanations see Fig. 3.

Another possible explanation is (2) that intermediate acetate is converted by syntrophic acetate oxidation instead of acetoclastic methanogenesis (Conrad et al., 2010a). Syntrophic acetate oxidation is the conversion of acetate to $\mathrm{CO}_{2}$ plus $\mathrm{H}_{2}$

$$
\mathrm{CH}_{3} \mathrm{OOH}+2 \mathrm{H}_{2} \mathrm{O} \rightarrow 4 \mathrm{H}_{2}+2 \mathrm{CO}_{2}
$$

followed by hydrogenotrophic methanogenesis Eq. (9). Such a pathway was detected in sediment of subtropical Lake Kinneret Nüsslein et al., 2001, 2003), but it disappeared again later on being replaced by acetoclastic methanogenesis (Schwarz et al., 2007b). We cannot completely exclude syntrophic acetate oxidation in the Brazilian lake sediments, but note that syntrophic acetate oxidizers would then have to be sensitive to $\mathrm{CH}_{3} \mathrm{~F}$ inhibition similarly as acetoclastic methanogens. Otherwise the accumulation of acetate in the presence of $\mathrm{CH}_{3} \mathrm{~F}$ could not be explained. Furthermore, all the lake sediments contained archaeal 16S rRNA sequences of putative acetoclastic Methanosaeta (Table 4), so that acetate could well have been consumed by methanogens rather than syntrophic acetate oxidizers.

As further possible explanation (3) some of the $\mathrm{CH}_{4}$ may have been produced not only from $\mathrm{H}_{2} / \mathrm{CO}_{2}$ and acetate but also from methanol.

$$
4 \mathrm{CH}_{3} \mathrm{OH} \rightarrow 3 \mathrm{CH}_{4}+\mathrm{CO}_{2}+2 \mathrm{H}_{2} \mathrm{O}
$$

Methanol is a product of microbial pectin degradation (Schink and Zeikus, 1982). However, the amount of methanol produced from pectin to that of acetate and $\mathrm{H}_{2}$, which are also produced, would account for less than $25 \%$ of pectin-derived $\mathrm{CH}_{4}$ production. In fact, whenever methylotrophic methanogenesis was quantified in freshwater environments by tracer experiments, it was found to contribute less than 5\% and thus was considered to be negligible (Conrad and Claus, 2005; Lovley and Klug, 1983). Conversion of methanol to $\mathrm{CH}_{4}$ exhibits a large isotopic enrichment factor $\left(\varepsilon \mathrm{CH}_{3} \mathrm{OH}, \mathrm{CH}_{4}=-74 \%\right.$ o $)$ similar to that of hydrogenotrophic methanogenesis (Krzycki et al., 1987). Therefore, contribution of methanol to $\mathrm{CH}_{4}$ formation can hardly be detected against a background of other processes that also produce relatively ${ }^{13} \mathrm{C}$-depleted $\mathrm{CH}_{4}$ (Conrad and Claus, 2005). Thus, hydrogenotrophic methanogenesis could be mistaken as methylotrophic methanogenesis and vice versa. However, since methanol is probably as rapidly consumed as it is produced, isotope fractionation is unlikely. Only a limited number of methanogenic species within the family Methanosearcinaceae are able to convert methanol to $\mathrm{CH}_{4}$. Recently, such methanogens were found to exhibit a remarkable potential of $\mathrm{CH}_{4}$ production from methanol in sediment from the Tibet plateau, but it is still unclear whether this potential is also relevant at in-situ conditions (Zhang et al., 2008). Considering all these arguments we believe that methylotrophic methanogenesis and syntrophic acetate oxidation are unlikely to explain a major percentage of $\mathrm{CH}_{4}$ production. Instead, we think that incomplete degradation of organic matter with preferential production of $\mathrm{H}_{2}$ is the more likely explanation for the relatively high values of $f_{\mathrm{CO}_{2}, \mathrm{CH}_{4}}$ determined.

Values of $f_{\mathrm{CO}_{2}, \mathrm{CH}_{4}}$ were not significantly correlated with the relative abundance of any of the methanogenic groups determined by T-RFLP analysis (Table 4). However, $f_{\mathrm{CO}_{2}, \mathrm{CH}_{4}}$ in the different lake sediments showed a slightly increasing tendency with the percentage abundance of Methanosarcinaceae (Fig. 8a) and slightly decreasing one with the Methanosaetaceae (Fig. 8b), albeit both being statistically not significant. These tendencies are consistent with the assumption that Methanosarcinaceae and Methanosaetaceae were involved in hydrogenotrophic and acetoclastic methanogenesis, respectively, which is a reasonable assumption. Values of $f_{\mathrm{CO}_{2}, \mathrm{CH}_{4}}$ also increased with the percentage 
of all putatively hydrogenotrophic methanogens (i.e., T-RFs of 92,186 , and $393 \mathrm{bp}$ ), but again far below the level of statistic significance. Nevertheless, these observations are encouraging for future research to eventually reveal a significant relation between microbial community patterns and microbial functionality if sufficient lake sediments are tested for relevant microbial genes and their transcription.

\subsection{Carbon isotope fractionation during acetate production}

The isotopic signature of the acetate may be indicative for the processes being involved in acetate production and/or consumption (Heuer et al., 2010). While the kinetic isotope effect during acetate consumption would always result in the residual acetate being ${ }^{13} \mathrm{C}$-enriched, that during acetate production would either result in only little fractionation (fermentation) or in a significant ${ }^{13} \mathrm{C}$-depletion (homoacetogenesis) of the produced acetate with respect to its substrate (Heuer et al., 2010).

Acetate consumption most likely occurred by acetoclastic methanogenesis because of acetate accumulation in the presence of $\mathrm{CH}_{3} \mathrm{~F}$, an inhibitor of acetoclastic methanogens (Janssen and Frenzel, 1997). Syntrophic acetate oxidation may also have contributed to acetate consumption, but substantial contribution was only likely if this process was sensitive to $\mathrm{CH}_{3} \mathrm{~F}$ inhibition, which is not known. Acetate oxidation by sulfate reduction or reduction of other electron acceptors (e.g., ferric iron) is unlikely for the same reasons. Furthermore, $\mathrm{CH}_{4}$ production should then have started with a lag phase, which was not observed (except lake \#8; see 4.2 above). Assimilation of acetate into biomass can be neglected, since microbial growth was most probably negligible during the time sediment was incubated (see 4.2 above).

The $\delta^{13} \mathrm{C}$ values of total acetate in the presence of $\mathrm{CH}_{3} \mathrm{~F}$ were sometimes lower and sometimes higher than those in the absence (Table 3). Across all the different lake sediments, however, the two data sets of $\delta^{13} \mathrm{C}_{\mathrm{ac}}$ were correlated to each other in an almost proportional way (Fig. 9a), indicating that on the average, acetate was not fractionated during consumption by $\mathrm{CH}_{3} \mathrm{~F}$-sensitive processes like acetoclastic methanogenesis. The same was true for the $\delta^{13} \mathrm{C}$ values of acetatemethyl, albeit exhibiting a larger variability. This observation does not exclude that aceate is fractionated in individual lake sediments. Indeed, a higher $\delta^{13} \mathrm{C}$ value in the absence versus the presence of $\mathrm{CH}_{3} \mathrm{~F}$, as theoretically expected for ongoing fractionation, was observed in several sediments (Figs. 9a, 10 , Table 3), indicating $\varepsilon_{\mathrm{ac}, \mathrm{CH}_{4}} \geq-10 \%$. Such fractionation is consistent with the operation of acetoclastic Methanosaeta species, which we also used as a possible condition for the determination of the fraction $\left(f_{\mathrm{CO}_{2}, \mathrm{CH}_{4}}\right)$ of hydrogenotrophically produced $\mathrm{CH}_{4}$ (see 4.3 above). Syntrophic acetate oxidation was recently found to fractionate acetate similarly $\left(\varepsilon_{\mathrm{ac}, \mathrm{CH}_{4}} \geq-10 \%\right.$ ) (Conrad and Klose, 2011). Therefore, the $\delta^{13} \mathrm{C}$ values of acetate do not allow discrimination be- tween the operation of acetoclastic methanogenesis versus syntrophic acetate oxidation.

We may assume that the $\delta^{13} \mathrm{C}$ values of acetate accumulated in the presence of $\mathrm{CH}_{3} \mathrm{~F}$ were largely due to ${ }^{13} \mathrm{C}$-isotope fractionation during acetate production. Acetate may be produced by either fermentation of organic substrates (primary or secondary fermentation) or by homoacetogenesis. Homoacetogenesis is achieved by either chemolithoautotrophic homoacetogenesis, organoautotrophic or organoheterotrophic homoacetogenesis (Lever et al., 2010). While fermentative production of acetate is accompanied by little isotope fractionation of only a few permil (Blair et al., 1985; Penning and Conrad, 2006; Rinaldi et al., 1974), chemolithoautrophic acetate production exhibits a large fractionation with acetate being ${ }^{13} \mathrm{C}$-depleted relative to $\mathrm{CO}_{2}$ by about $59 \%$ (Gelwicks et al., 1989). The acetate produced during organoautotrophic or organoheterotrophic homoacetogenesis is most likely also ${ }^{13} \mathrm{C}$-depleted relative to the substrate, albeit this has not yet been determined explicitly using microbial cultures (Lever et al., 2010).

Values of $\delta^{13} \mathrm{C}_{\mathrm{ac}-\mathrm{CH}_{3} \mathrm{~F}}$ were positively correlated to $\delta^{13} \mathrm{C}_{\text {org }}$, albeit with a slope larger than 2 (Fig. 9b), indicating that organic carbon was a source of acetate. Heuer et al. (2010) investigated two German lake sediments and

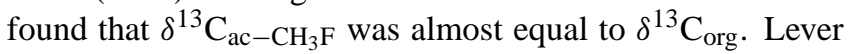
et al. (2010) investigated the vertical profile of a marine sediment and found that $\delta^{13} \mathrm{C}_{\mathrm{ac}}$ values were lower than $\delta^{13} \mathrm{C}_{\mathrm{org}}$. In our samples, five out of 16 lake sediments exhibited a $\delta^{13} \mathrm{C}_{\mathrm{ac}-\mathrm{CH}_{3} \mathrm{~F}}$ lower than $\delta^{13} \mathrm{C}_{\mathrm{org}}$, but most of the samples ex-

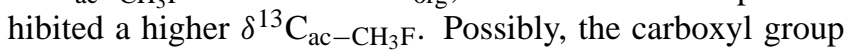
of acetate partially exchanged with the environmental $\mathrm{CO}_{2}$ (DeGraaf et al., 1996), thus affecting the $\delta^{13} \mathrm{C}$ of total acetate. However, it is unclear whether such an exchange reaction operates, since $\delta^{13} \mathrm{C}$ values of total acetate seem to discriminate well between the different processes involved (Heuer et al., 2010).

The $\delta^{13} \mathrm{C}$ of acetate-methyl was generally lower than $\delta^{13} \mathrm{C}_{\text {org. }}$. Furthermore, $\delta^{13} \mathrm{C}_{\mathrm{ac}-\text { methyl }}$ increased at the same rate (relative slope $=1.1$ ) as $\delta^{13} \mathrm{C}$ of $\mathrm{C}_{\text {org }}$ (Fig. 9c) as theoretically expected. However, it should be noted that the linear regression was not statistically significant for the number of data available. Nevertheless, the $\delta^{13} \mathrm{C}$ of acetate-methyl was on the average by $10 \%$ lower than that of $\mathrm{C}_{\text {org }}$ indicating some fractionation, possibly during fermentative acetate production. Previous studies in lake sediments also found that acetate-methyl was more negative than $\delta^{13} \mathrm{C}_{\mathrm{org}}$, the difference ranging between 0 and 10\%o (Conrad et al., 2007, 2009, 2010b). Here, however, we observed a much larger range of 4-40\%o. The smaller values can be explained from experiments with pure cultures of fermenting bacteria, in which $\delta^{13} \mathrm{C}$ of acetate was only slightly different from $\delta^{13} \mathrm{C}$ of the substrate (Blair et al., 1985; Penning and Conrad, 2006; Rinaldi et al., 1974). However, for $\delta^{13} \mathrm{C}_{\mathrm{ac}-\text { methyl }}$ being $40 \%$ more negative than $\delta^{13} \mathrm{C}_{\text {org }}$ there is no immediate explanation, except that the effective substrate from 

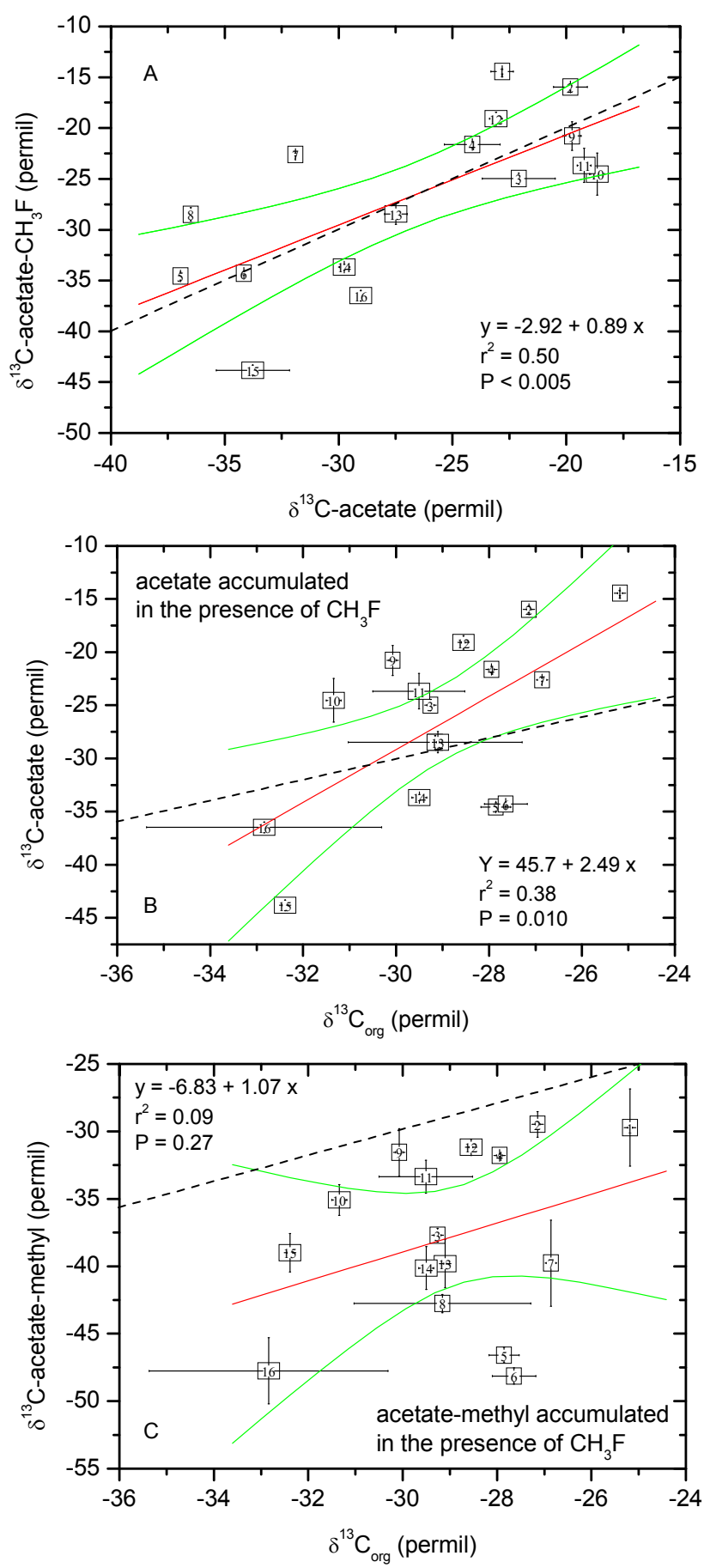

Fig. 9. Linear regression of the $\delta^{13} \mathrm{C}$ of total acetate and acetatemethyl against the $\delta^{13} \mathrm{C}$ of sediment organic matter determined in 16 different lake sediments; (A) average $\delta^{13} \mathrm{C}$ of total acetate formed in the presence of $\mathrm{CH}_{3} \mathrm{~F}$ against that formed in the absence of $\mathrm{CH}_{3} \mathrm{~F}$; (B) average $\delta^{13} \mathrm{C}$ of total acetate formed in the presence of $\mathrm{CH}_{3} \mathrm{~F}$ against $\delta^{13} \mathrm{C}$ of sediment organic carbon; $(\mathbf{C})$ average $\delta^{13} \mathrm{C}$ of acetate-methyl formed in the presence of $\mathrm{CH}_{3} \mathrm{~F}$ against $\delta^{13} \mathrm{C}$ of sediment organic carbon; other explanations see Fig. 3.
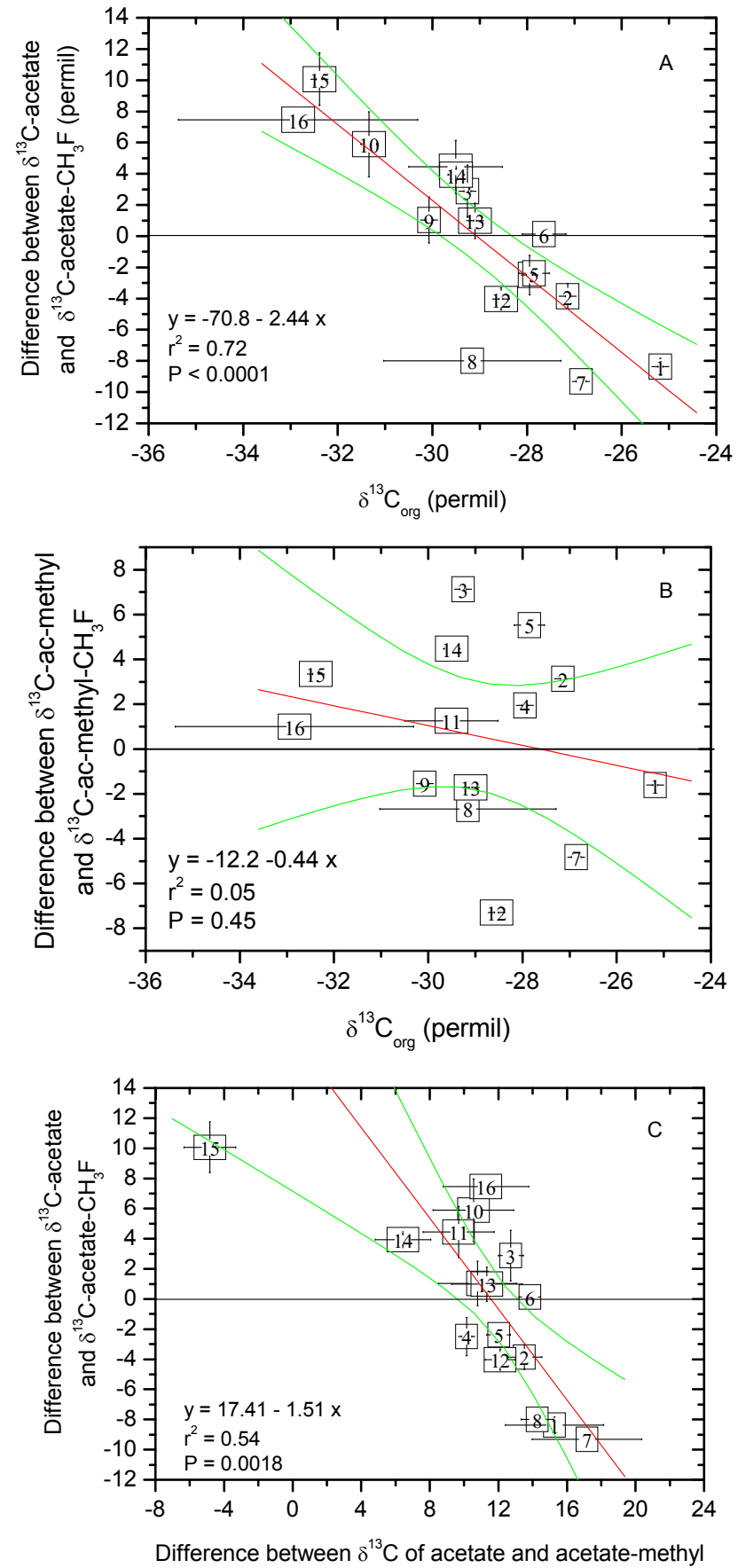

Fig. 10. Linear regression of the difference between the $\delta^{13} \mathrm{C}$ of acetate or acetate-methyl measured in the absence and presence of $\mathrm{CH}_{3} \mathrm{~F}$ (Difference $=\delta^{13} \mathrm{C}_{\mathrm{ac}}-\delta^{13} \mathrm{C}_{\mathrm{ac}}-\mathrm{CH}_{3} \mathrm{~F}$ ) in 16 different lake sediments; (A) regression against the $\delta^{13} \mathrm{C}$ of sediment organic matter using $\delta^{13} \mathrm{C}$ of total acetate; (B) regression against the $\delta^{13} \mathrm{C}$ of sediment organic matter using $\delta^{13} \mathrm{C}$ of acetate-methyl; (C) regression against the acetate-intramolecular difference of $\delta^{13} \mathrm{C}$ (Difference $\left.=\delta^{13} \mathrm{C}_{\mathrm{ac}}-\delta^{13} \mathrm{C}_{\mathrm{ac}-\text { methyl }}\right)$; other explanations see Fig. 3. 
which acetate was produced may have been more negative than the $\delta^{13} \mathrm{C}_{\text {org }}$ measured or the isotope effect involved was much larger than expected, perhaps including chemolithoautortrophic homoacetogenesis in some of the lake sediments.

We also found in some of the sediments that the $\delta^{13} \mathrm{C}$ of accumulated acetate was higher in the presence than in the absence of $\mathrm{CH}_{3} \mathrm{~F}$. The difference was only $<10 \%$, and was larger for total acetate (Fig. 10a) than for acetate-methyl (Fig. 10b), but it was the same lake sediments where acetate carbon was fractionated this way. This way of fractionation is not expected. An analysis of the difference between the $\delta^{13} \mathrm{C}_{\mathrm{ac}}$ and $\delta^{13} \mathrm{C}_{\mathrm{ac}-\mathrm{CH} 3 \mathrm{~F}}$ showed that it was negatively correlated with $\delta^{13} \mathrm{C}_{\text {org }}$ and changed from a positive to a negative value at a $\delta^{13} C_{\text {org }}$ of about $-30 \%$ (Fig. 10a). A similar relationship was obtained using acetate-methyl instead of total acetate but was not significant (Fig. 10b). The difference

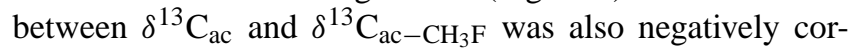
related with the intramolecular isotopic difference between carboxyl and methyl groups of acetate (as seen from the difference between $\delta^{13} \mathrm{C}_{\mathrm{ac}}$ and $\delta^{13} \mathrm{C}_{\mathrm{ac}-\text { methyl }}$ ) (Fig. 10c). However, the difference between $\delta^{13} \mathrm{C}_{\mathrm{ac}}$ and $\delta^{13} \mathrm{C}_{\mathrm{ac}}-\mathrm{CH}_{3} \mathrm{~F}$ exhibited no significant correlation with other parameters, such as $\mathrm{CH}_{4}$ production rate, fraction of hydrogenotrophic methanogenesis, fractionation factors, microbial numbers, etc. Such a counterintuitive fractionation of acetate carbon had also been observed in the sediment of a German lake (Conrad et al., 2009).

In chemolithoautotrophic homoacetogenesis, acetate is synthesized from $\mathrm{CO}_{2}$ (i.e., reversal of Eq. (10). The acetate synthesized in this way exhibits only a small isotopic difference between methyl and carboxyl groups being on the order of $<2 \%$ (Gelwicks et al., 1989). The acetate synthesized during fermentation, on the other hand, may have a much larger intramolecular isotopic difference being on the order of $24 \%$ (Blair et al., 1985). In the Brazilian lake sediments, the difference between $\delta^{13} \mathrm{C}_{\mathrm{ac}}$ and $\delta^{13} \mathrm{C}_{\mathrm{ac}-\text { methyl }}$ was between 5\%o and 17\%o (except Lake \#15, Paca, Fig. 5) which corresponds to an intramolecular isotopic difference of $12-30 \%$. We hypothesize, similarly as before (Conrad et al., 2009), that acetate was mainly produced by fermentation production and that fermentation was partially inhibited by $\mathrm{CH}_{3} \mathrm{~F}$ in such a way, that carbon isotope fractionation was affected. This could happen when different fermenting microorganisms exhibit different isotope fractionation and different susceptibility to inhibition by $\mathrm{CH}_{3} \mathrm{~F}$. There are hardly studies of isotope fractionation during fermentative acetate production (Blair et al., 1985; Penning and Con$\mathrm{rad}, 2006)$ although numerous different fermentation pathways exist in nature. However, there may be alternative explanations, e.g., acetate production by organoautotrophic or organoheterotrophic homoacetogenesis from which we do not know the intramolecular isotopic difference between carboxyl and methyl of acetate (Lever et al., 2010), or exchange reactions (DeGraaf et al., 1996).

\section{Conclusions}

The study of various tropical lake sediments from Brazil demonstrated that production rates of $\mathrm{CH}_{4}$ and $\mathrm{CO}_{2}$ increased with the content of organic matter showing that the availability of substrate may limit the methanogenic degradation process.

The isotopic data were a function of both the $\delta^{13} \mathrm{C}$ of the primary substrate (organic matter) and the path of $\mathrm{CH}_{4}$ production. In the tropical lake sediments the path of $\mathrm{CH}_{4}$ production seems to be dominated by hydrogenotrophic methanogenesis that exhibited relatively strong isotope fractionation with $\delta^{13} \mathrm{C}_{\mathrm{CH}_{4}}$ being by about $43 \%$ o lower than $\delta^{13} \mathrm{C}_{\text {org }}$, and acetate was probably produced mainly by fermentation. For the time being it remains unclear which environmental factors determine the relative importance of hydrogenotrophic versus acetoclastic methanogenesis. The overall abundance of bacteria and archaea correlated well with the production rates of $\mathrm{CH}_{4}$ and $\mathrm{CO}_{2}$ showing that methanogenic degradation of organic matter is dependent on and may be limited by microbial activity. However, the study revealed no apparent correlation of the $\mathrm{CH}_{4}$ production rates, the ${ }^{13} \mathrm{C}$ stable isotope discrimination, or the path of $\mathrm{CH}_{4}$ production with the diversity or the composition of the resident methanogenic microbial communities. Although this result does not exclude that not-measured microbial parameters, e.g., the extent of gene expression or protein synthesis in the different groups of bacteria and archaea, do have a decisive effect on $\mathrm{CH}_{4}$ production, it nevertheless indicates that the relative abundance of a particular microbial population is of little importance.

\section{Supplementary material related to this article is available online at: http://www.biogeosciences.net/8/795/2011/ bg-8-795-2011-supplement.pdf.}

Acknowledgements. We would like to thank Juliana Menezes for help during the field sampling, four anonymous reviewers for their constructive comments, and the Fonds der Chemischen Industrie for financial support. Alex Enrich Prast and Wanderley R. Bastos received research fellowships from the Brazilian Research Council (CNPq).

The service charges for this open access publication have been covered by the Max Planck Society.

Edited by: K. Küsel 


\section{References}

Alperin, M. J., Blair, N. E., Albert, D. B., Hoehler, T. M., and Martens, C. S.: Factors that control the stable carbon isotopic composition of methane produced in an anoxic marine sediment, Global Biogeochem. Cy., 6, 271-291, 1992.

Amann, R. I., Ludwig, W., and Schleifer, K. H.: Phylogenetic identification and in situ detection of individual microbial cells without cultivation, Microbiol. Rev., 59, 143-169, 1995.

Avery, G. B., Shannon, R. D., White, J. R., Martens, C. S., and Alperin, M. J.: Effect of seasonal changes in the pathways of methanogenesis on the $\mathrm{d}^{13} \mathrm{C}$ values of pore water methane in a Michigan peatland, Global Biogeochem. Cy., 13, 475-484, 1999.

Bastviken, D., Cole, J., Pace, M., and Tranvik, L.: Methane emissions from lakes: Dependence of lake characteristics, two regional assessments, and a global estimate, Global Biogeochem. Cy., 18, GB4009, doi:10.1029/2004GB002238, 2004.

Bastviken, D., Santoro, A. L., Marotta, H., Pinho, L. Q., Calheiros, D. F., Crill, P., and Enrich-Prast, A.: Methane emission from Pantanal, South America, during low water season: toward more comprehensive sampling, Environ. Sci. Technol., 44, 5450-5455, 2010.

Bastviken, D., Tranvik, L. J., Downing, J. A., Crill, P. M., and Enrich-Prast, A.: Freshwater methane emissions offset the continental carbon sink, Science, 331, 50, doi:10.1126/science.1196808, 2011.

Bent, S. J. and Forney, L. J.: The tragedy of the uncommon: understanding limitations in the analysis of microbial diversity (Review), ISME J. 2, 689-695, 2008.

Billen, G.: Modelling the processes of organic matter degradation and nutrients recycling in sedimentary systems, in: Sediment Microbiology, edited by: Nedwell, D. B. and Brown, C. M., 15-52, Academic Press, 1982.

Blair, N., Leu, A., Munoz, E., Olsen, J., Kwong, E., and DesMarais, D.: Carbon isotopic fractionation in heterotrophic microbial metabolism, Appl. Environ. Microbiol., 50, 996-1001, 1985.

Chan, O. C., Claus, P., Casper, P., Ulrich, A., Lueders, T., and Conrad, R.: Vertical distribution of structure and function of the methanogenic archaeal community in Lake Dagow sediment, Environ. Microbiol., 7, 1139-1149, 2005.

Cicerone, R. J. and Oremland, R. S.: Biogeochemical aspects of atmospheric methane, Global Biogeochem. Cy., 2, 299-327, 1988.

Conrad, R.: Contribution of hydrogen to methane production and control of hydrogen concentrations in methanogenic soils and sediments (review), FEMS Microbiol. Ecol., 28, 193-202, 1999.

Conrad, R.: Quantification of methanogenic pathways using stable carbon isotopic signatures: a review and a proposal, Org. Geochem., 36, 739-752, 2005.

Conrad, R.: Soil microbial communities and global climate change - methanotrophic and methanogenic communities as paradigms, in: Modern Soil Microbiology: Second Edition, edited by: VanElsas, J. D., Jansson, J., and Trevors, J. T., 263-282, CRC Press, 2007.

Conrad, R. and Klose, M.: How specific is the inhibition by methyl fluoride of acetoclastic methanogenesis in anoxic rice field soil?, FEMS Microbiol. Ecol., 30, 47-56, 1999.

Conrad, R. and Claus, P.: Contribution of methanol to the production of methane and its ${ }^{13} \mathrm{C}$-isotopic signature in anoxic rice field soil, Biogeochem., 73, 381-393, 2005.
Conrad, R. and Klose, M.: Dynamics of the methanogenic archaeal community in anoxic rice soil upon addition of straw, Eur. J. Soil Sci., 57, 476-484, 2006.

Conrad, R. and Klose, M.: Stable carbon isotope discrimination in rice field soil during acetate turnover by syntrophic acetate oxidation or acetoclastic methanogenesis, Geochim. Cosmochim. Ac., 75, 1531-1539, 2011.

Conrad, R., Chan, O. C., Claus, P., and Casper, P.: Characterization of methanogenic Archaea and stable isotope fractionation during methane production in the profundal sediment of an oligotrophic lake (Lake Stechlin, Germany), Limnol. Oceanogr., 52, 13931406, 2007.

Conrad, R., Klose, M., Noll, M., Kemnitz, D., and Bodelier, P. L. E.: Soil type links microbial colonization of rice roots to methane emission, Global Change Biol., 14, 657-669, 2008.

Conrad, R., Claus, P., and Casper, P.: Characterization of stable isotope fractionation during methane production in the sediment of a eutrophic lake, Lake Dagow, Germany, Limnol. Oceanogr., 54, 457-471, 2009.

Conrad, R., Claus, P., and Casper, P.: Stable isotope fractionation during the methanogenic degradation of organic matter in the sediment of an acidic bog lake, Lake Grosse Fuchskuhle, Limnol. Oceanogr., 55, 1932-1942, 2010a.

Conrad, R., Klose, M., Claus, P., and Enrich-Prast, A.: Methanogenic pathway, ${ }^{13} \mathrm{C}$ isotope fractionation, and archaeal community composition in the sediment of two clearwater lakes of Amazonia, Limnol. Oceanogr., 55, 689-702, $2010 \mathrm{~b}$.

DeGraaf, W., Wellsbury, P., Parkes, R. J., and Cappenberg, T. E.: Comparison of acetate turnover in methanogenic and sulfatereducing sediments by radiolabeling and stable isotope labeling and by use of specific inhibitors: Evidence for isotopic exchange, Appl. Environ. Microbiol., 62, 772-777, 1996.

Devol, A. H., Richey, J. E., Forsberg, B. R., and Martinelli, L. A.: Seasonal dynamics in methane emissions from the Amazon River floodplain to the troposphere, J. Geophys. Res., 95, 1641716426, 1990.

Dolfing, J.: Acetogenesis, in: Biology of Anaerobic Microorganisms, eduted by: Zehnder, A. J. B., 417-468, Wiley, 1988.

Drake, H. L. and Küsel, K.: How the diverse physiologic potentials of acetogens determine their in situ realities (review), in: Biochemistry and Physiology of Anaerobic Bacteria, edited by: Ljungdahl, L. G., Adams, M. W., Barton, L. L., Ferry, J. G., and Johnson, M. K., 171-190, Springer, 2003.

Galand, P. E., Yrjälä, K., and Conrad, R.: Stable carbon isotope fractionation during methanogenesis in three boreal peatland ecosystems, Biogeosciences, 7, 3893-3900, doi:10.5194/bg-73893-2010, 2010.

Gelwicks, J. T., Risatti, J. B., and Hayes, J. M.: Carbon isotope effects associated with autotrophic acetogenesis, Org. Geochem., 14, 441-446, 1989.

Gelwicks, J. T., Risatti, J. B., and Hayes, J. M.: Carbon isotope effects associated with aceticlastic methanogenesis, Appl. Environ. Microbiol., 60, 467-472, 1994.

Goevert, D. and Conrad, R.: Effect of substrate concentration on carbon isotope fractionation during acetoclastic methanogenesis by Methanosarcina barkeri and M. acetivorans and in rice field soil, Appl. Environ. Microbiol., 75, 2605-2612, 2009.

Hayes, J. M.: Factors controlling ${ }^{13} \mathrm{C}$ contents of sedimentary organic compounds: principles and evidence, Mar. Geol., 113, 
111-125, 1993.

Heitmann, T., Goldhammer, T., Beer, J., and Blodau, C.: Electron transfer of dissolved organic matter and its potential significance for anaerobic respiration in a northern bog, Global Change Biol., 13, 1771-1785, 2007.

Heuer, V. B., Krüger, M., Elvert, M., and Hinrichs, K. U.: Experimental studies on the stable carbon isotope biogeochemistry of acetate in lake sediments, Org. Geochem., 41, 22-30, 2010.

Hornibrook, E. R. C., Longstaffe, F. J., and Fyfe, W. S.: Evolution of stable carbon isotope compositions for methane and carbon dioxide in freshwater wetlands and other anaerobic environments, Geochim. Cosmochim. Ac., 64, 1013-1027, 2000.

Janssen, P. H. and Frenzel, P.: Inhibition of methanogenesis by methyl fluoride - studies of pure and defined mixed cultures of anaerobic bacteria and archaea, Appl. Environ. Microbiol., 63, 4552-4557, 1997.

Keller, J. K., Weisenhorn, P. B., and Megonigal, J. P.: Humic acids as electron acceptors in wetland decomposition, Soil Biol. Biochem., 41, 1518-1522, 2009.

Klappenbach, J. A., Saxman, P. R., Cole, J. R., and Schmidt, T. M.: rrndb: the ribosomal RNA Operon Copy Number Database, Nucleic Acids Res., 29, 181-184, 2001.

Koizumi, Y., Takii, S., Nishino, M., and Nakajima, T.: Vertical distributions of sulfate-reducing bacteria and methane-producing archaea quantified by oligonucleotide probe hybridization in the profundal sediment of a mesotrophic lake, FEMS Microbiol. Ecol., 44, 101-108, 2003.

Kolb, S., Knief, C., Dunfield, P. F., and Conrad, R.: Abundance and activity of uncultured methanotrophic bacteria involved in the consumption of atmospheric methane in two forest soils, Environ. Microbiol., 7, 1150-1161, 2005.

Krzycki, J. A., Kenealy, W. R., DeNiro, M. J., and Zeikus, J. G.: Stable carbon isotope fractionation by Methanosarcina barkeri during methanogenesis from acetate, methanol, or carbon dioxide-hydrogen, Appl. Environ. Microbiol., 53, 2597-2599, 1987.

Lelieveld, J., Crutzen, P. J., and Dentener, F. J.: Changing concentrations, lifetime and climate forcing of atmospheric methane, Tellus, 50B, 128-150, 1998.

Lever, M. A., Alperin, M. J., Teske, A., Heuer, V. B., Schmidt, F., Hinrichs, K. U., Morono, Y., Masui, N., and Inagaki, F.: Acetogenesis in deep subseafloor sediments of the Juan de Fuca Ridge flank: a synthesis of geochemical, thermodynamic, and genebased evidence, Geomicrobiol. J., 27, 183-211, 2010.

Lovley, D. R. and Klug, M. J.: Methanogenesis from methanol and methylamines and acetogenesis from hydrogen and carbon dioxide in sediments of a eutrophic lake, Appl. Environ. Microbiol., 45, 1310-1315, 1983.

Lueders, T., Chin, K. J., Conrad, R., and Friedrich, M.: Molecular analyses of methyl-coenzyme $\mathrm{M}$ reductase alpha-subunit $(m c r A)$ genes in rice field soil and enrichment cultures reveal the methanogenic phenotype of a novel archaeal lineage, Environ. Microbiol., 3, 194-204, 2001.

Marani, L. and Alvala, P. C.: Methane emissions from lakes and floodplains in Pantanal, Brazil, Atmos. Environ., 41, 1627-1633, 2007.

McInerney, M. J. and Bryant, M. P.: Basic principles of bioconversions in anaerobic digestion and methanogenesis, in: Biomass Conversion Processes for Energy and Fuels, edited by: Sofer, S.
S. and Zaborsky, O. R., 277-296, Plenum, 1981.

Noll, M., Klose, M., and Conrad, R.: Effect of temperature change on the composition of the bacterial and archaeal community potentially involved in the turnover of acetate and propionate in methanogenic rice field soil, FEMS Microbiol. Ecol., 73, 215225, 2010.

Nüsslein, B., Chin, K. J., Eckert, W., and Conrad, R.: Evidence for anaerobic syntrophic acetate oxidation during methane production in the profundal sediment of subtropical Lake Kinneret (Israel), Environ. Microbiol., 3, 460-470, 2001.

Nüsslein, B., Eckert, W., and Conrad, R.: Stable isotope biogeochemistry of methane formation in profundal sediments of Lake Kinneret (Israel), Limnol. Oceanogr., 48, 1439-1446, 2003.

Pace, N. R.: A molecular view of microbial diversity and the biosphere, Science, 276, 734-740, 1997.

Penning, H. and Conrad, R.: Carbon isotope effects associated with mixed-acid fermentation of saccharides by Clostridium papyrosolvens, Geochim. Cosmochim. Ac., 70, 2283-2297, 2006.

Penning, H., Plugge, C. M., Galand, P. E., and Conrad, R.: Variation of carbon isotope fractionation in hydrogenotrophic methanogenic microbial cultures and environmental samples at different energy status, Global Change Biol., 11, 2103-2113, 2005.

Penning, H., Claus, P., Casper, P., and Conrad, R.: Carbon isotope fractionation during acetoclastic methanogenesis by Methanosaeta concilii in culture and a lake sediment, Appl. Environ. Microbiol., 72, 5648-5652, 2006.

Quay, P. D., King, S. L., Stutsman, J., Wilbur, D. O., Steele, L. P., Fung, I., Gammon, R. H., Brown, T. A., Farwell, G. W., Grootes, P. M., and Schmidt, F. H.: Carbon isotopic composition of atmospheric CH4: fossil and biomass burning source strengths, Global Biogeochem. Cy., 5, 25-47, 1991.

Rappe, M. S. and Giovannoni, S. J.: The uncultured microbial majority, Ann. Rev. Microbiol., 57, 369-394, 2003.

Rinaldi, G., Meinschein, W. G., and Hayes, J. M.: Carbon isotope fractionations associated with acetic acid production by Acetobacter suboxydans, Biomed. Mass Spectrometry, 1, 412-414, 1974.

Rothfuss, F. and Conrad, R.: Thermodynamics of methanogenic intermediary metabolism in littoral sediment of Lake Constance, FEMS Microbiol. Ecol., 12, 265-276, 1993.

Schink, B. and Zeikus, J. G.: Microbial ecology of pectin decomposition in anoxic lake sediments, J. Gen. Microbiol., 128, 393404, 1982.

Schink, B. and Stams, A. J. M.: Syntrophism among prokaryotes, in: The Prokaryotes, Edn. 3, Vol. 2, edited by: Dworkin, M. Falkow, S., Rosenberg, E., Schleifer, K. H., and Stackebrandt, E., 309-335, Springer, 2006.

Schwarz, J. I. K., Eckert, W., and Conrad, R.: Community structure of Archaea and Bacteria in a profundal lake sediment Lake Kinneret (Israel), Syst. Appl. Microbiol., 30, 239-254, 2007a.

Schwarz, J. I. K., Lueders, T., Eckert, W., and Conrad, R.: Identification of acetate-utilizing Bacteria and Archaea in methanogenic profundal sediments of Lake Kinneret (Israel) by stable isotope probing of rRNA, Environ. Microbiol., 9, 223-237, 2007b.

Smith, L. K., Lewis, W. M., Chanton, J. P., Cronin, G., and Hamilton, S. K.: Methane emissions from the Orinoco River floodplain, Venezuela, Biogeochem., 51, 113-140, 2000.

Stumm, W. and Morgan, J. J.: Aquatic Chemistry, An Introduc- 
tion Emphasizing Chemical Equilibria in Natural Waters, Wiley, 1981.

Sugimoto, A. and Wada, E.: Carbon isotopic composition of bacterial methane in a soil incubation experiment: contributions of acetate and $\mathrm{CO}_{2} / \mathrm{H}_{2}$, Geochim. Cosmochim. Ac., 57, 4015-4027, 1993.

Takai, K., Nakamura, K., Toki, T., Tsunogai, U., Miyazaki, M., Miyazaki, J., Hirayama, H., Nakagawa, S., Nunoura, T., and Horikoshi, K.: Cell proliferation at $122^{\circ} \mathrm{C}$ and isotopically heavy $\mathrm{CH}_{4}$ production by a hyperthermophilic methanogen under highpressure cultivation, Proc. Natl. Acad. Sci. USA, 105, 1094910954, 2008.

Tijhuis, L., VanLoosdrecht, M. C. M., and Heijnen, J. J.: A thermodynamically based correlation for maintenance Gibbs energy requirements in aerobic and anaerobic chemotrophic growth, Biotechnol. Bioeng., 42, 509-519, 1993.

Tyler, S. C.: Kinetic isotope effects and their use in studying atmospheric trace species. Case study, $\mathrm{CH}_{4}+\mathrm{OH}$, edited by: Kaye, J. A., 390-408, American Chemical Society, 1992.

Valentine, D. L., Chidthaisong, A., Rice, A., Reeburgh, W. S., and Tyler, S. C.: Carbon and hydrogen isotope fractionation by moderately thermophilic methanogens, Geochim. Cosmochim. Ac., 68, 1571-1590, 2004.

Ward, D. M. and Winfrey, M. R.: Interactions between methanogenic and sulfate-reducing bacteria in sediments, Adv. Aquat. Microbiol., 3, 141-179, 1985.

Wassmann, R., Thein, U. G., Whiticar, M. J., Rennenberg, H., Seiler, W., and Junk, W. J.: Methane emissions from the Amazon floodplain: characterization of production and transport, Global Biogeochem. Cy., 6, 3-13, 1992.

Whiticar, M. J.: Carbon and hydrogen isotope systematics of bacterial formation and oxidation of methane, Chem. Geology, 161, 291-314, 1999.
Whiticar, M. J., Faber, E., and Schoell, M.: Biogenic methane formation in marine and freshwater environments: $\mathrm{CO}_{2}$ reduction vs. acetate fermentation - isotopic evidence, Geochim. Cosmochim. Ac., 50, 693-709, 1986.

Woese, C. R.: Interpreting the universal phylogenetic tree, Proc. Natl. Acad. Sci. USA, 97, 8392-8396, 2000.

Yavitt, J. B. and Seidmann-Zager, M.: Methanogenic conditions in northern peat soils, Geomicrobiol. J., 23, 119-127, 2006.

Zehnder, A. J. B.: Ecology of methane formation, in: Water Pollution Microbiology, edited by: Mitchell, R., Vol. 2., 349-376, Wiley, 1978.

Zepp-Falz, K., Holliger, C., Grosskopf, R., Liesack, W., Nozhevnikova, A. N., Müller, B., Wehrli, B., and Hahn, D.: Vertical distribution of methanogens in the anoxic sediment of Rotsee (Switzerland), Appl. Environ. Microbiol., 65, 2402-2408, 1999.

Zhang, C. L. L., Ye, Q., Reysenbach, A. L., Gotz, D., Peacock, A., White, D. C., Horita, J., Cole, D. R., Fong, J., Pratt, L., Fang, J. S., and Huang, Y. S.: Carbon isotopic fractionations associated with thermophilic bacteria Thermotoga maritima and Persephonella marina, Environ. Microbiol., 4, 58-64, 2002.

Zhang, G. S., Jiang, N., Liu, X. L., and Dong, X. Z.: Methanogenesis from methanol at low temperatures by a novel psychrophilic methanogen, "Methanolobus psychrophilus" sp nov., prevalent in Zoige wetland of the Tibetan plateau, Appl. Environ. Microbiol., 74, 6114-6120, 2008.

Zinder, S. H.: Physiological ecology of methanogens, in: Methanogenesis. Ecology, Physiology, Biochemistry and Genetics, edited by: Ferry, J. G., 128-206, Chapman \& Hall, 1993. 